\title{
GATE Center of Excellence at UAB in Lightweight Materials for Automotive Applications DE-FG26-05NT42620
}

\section{Final Report October 2005-August 2011}

This report summarizes the accomplishments of the UAB GATE Center of Excellence in Lightweight Materials for Automotive Applications. The first Phase of the UAB DOE GATE center spanned the period 2005-2011. This report covers the following:
A. Goals and Objectives
B. GATE Faculty
C. GAT Advisory Board
D. GATE Fellows and GATE Undergraduate Students
E. GATE courses
F. Publications/Patents by GATE fellows
G. Intellectual Property/Patent
H. Summer Student Training, Workshops and Other Training Activities
I. Collaborations/Interactions with State Automotive Companies
J. Other Relevant Interactions and GATE Leverage
K. Interaction with Oak Ridge National Laboratory
L. GATE seminar speakers
M. Summary and Overall Accomplishments

\section{A. UAB GATE GOALS AND OBJECTIVES}

The UAB GATE goals coordinated with the overall goals of DOE's FreedomCAR and Vehicles Technologies initiative and DOE GATE program. The FCVT goals are:

- Development and validation of advanced materials and manufacturing technologies to significantly reduce automotive vehicle body and chassis weight without compromising other attributes such as safety, performance, recyclability, and cost.

- To provide a new generation of engineers and scientists with knowledge and skills in advanced automotive technologies.

The UAB GATE focused on both the FCVT and GATE goals in the following manner:

- Train and produce graduates in lightweight automotive materials technologies

- $\quad$ Structure the engineering curricula to produce specialists in the automotive area

- Leverage automotive related industry in the State of Alabama

- $\quad$ Expose minority students to advanced technologies early in their career

- Develop innovative virtual classroom capabilities tied to real manufacturing operations

- Integrate synergistic, multi-departmental activities to produce new product and manufacturing technologies for more damage tolerant, cost-effective, and lighter automotive structures. 


\section{DISCLAIMER}

This report was prepared as an account of work sponsored by an agency of the United States Government. Neither the United States Government nor any agency thereof, nor any of their employees, makes any warranty, express or implied, or assumes any legal liability or responsibility for the accuracy, completeness, or usefulness of any information, apparatus, product, or process disclosed, or represents that its use would not infringe privately owned rights. Reference herein to any specific commercial product, process, or service by trade name, trademark, manufacturer, or otherwise does not necessarily constitute or imply its endorsement, recommendation, or favoring by the United States Government or any agency thereof. The views and opinions of authors expressed herein do not necessarily state or reflect those of the United States Government or any agency thereof. 


\section{B. GATE FACULTY}

The UAB GATE faculty team comprised of GATE administration - Uday Vaidya, Professor of Materials Science and (Principal Investigator), J. Barry Andrews (Project Director), George Husman (Industry advisory board chair) and GATE faculty and staff members - Alan M Shih; Alan W Eberhardt; Charles E Bates; John Griffin, Selvum Pillay, Chih-Hsiung Cheng; Derrick R Dean; Haibin Ning, Krishnabalaji Thattai and Nasim Uddin.

- Uday Vaidya (GATE PI), Professor, Department of Materials Science \& Engineering, 20+ years research and education experience in advanced composites and plastics.

- J. Barry Andrews (GATE PD), Chair, Department of Materials Science \& Engineering (MSE), 30+ years at UAB, research emphasis, lightweight metals and solidification.

- George Husman (Industry Advisory Board Chair)

- Alan Shih, Research Professor, Department of Mechanical Engineering, 20+ experience in computational mechanics and modeling

- Selvum (Brian) Pillay, Associate Professor, 6 year experience in Automotive industry; 15+ years in academics, Composites Manufacturing and Tooling, Applications Development and Evaluation.

- Charles Bates, Research Professor, 30+ years experience in metals casting

- John Griffin, Research Assistant Professor, Director of Castings Laboratory, 30+ years experience in metal casting technologies, lost foam and other advanced technologies.

- Gary Cheng, Associate Professor, Department of Mechanical Engineering, 13+ years experience in industry and academia on computational flow modeling and analysis.

- Alan Eberhardt, Professor, Department of Biomedical Engineering, 9+ years experience in biomechanics, impact and falls, injury science.

- Derrick Dean, Associate Professor, Department of Materials Science \& Engineering, 13+ years experience in industry and academia on polymers and nanomaterials.

- Haibin Ning, Assistant Professor, Design, Modeling and Finite Element Analysis

- Krishnabalaji Thattai, Research Associate, Manufacturing of Composites

\section{GATE ADVISORY BOARD}

The advisory board of the UAB GATE that met (or conferenced) twice a year on an average has been chaired by George Husman, Director of Engineering Research at UAB. The board members comprised Dan McKay (CEO, Polymer Technologies), Lou Ludteke (CEO, National Composite Center), David Warren, Office of Transportation Technologies (Oak Ridge National Laboratory) and Dr. Bharat Soni (UAB, Chair of the Mechanical Engineering department).

\section{GATE FELLOWS AND UNDERGRADUATE GATE STUDENTS}

Table 1 lists the GATE funded fellows and their research topics; and Table 2 lists the undergraduate pipeline students to motivate them to pursue graduate studies. The GATE fellows were either fully supported or partially supported through the DOE GATE funding. PhD, MS and BS level students were trained in technology areas critical to DOE. 
Table 1. GATE FELLOWS AND UNDERGRADUATE STUDENTS AND WHERE ARE THEY NOW?

\begin{tabular}{|c|c|c|c|c|}
\hline & $\begin{array}{l}\text { Student } \\
\text { Name }\end{array}$ & $\begin{array}{l}\text { Department and } \\
\text { Standing }\end{array}$ & $\begin{array}{l}\text { Thesis / } \\
\text { Research }\end{array}$ & Where Placed \\
\hline 1 & $\begin{array}{l}\text { Mohammed } \\
\text { Shohel }\end{array}$ & $\begin{array}{l}\text { Civil and } \\
\text { Environmental } \\
\text { Engineering, PhD } \\
\text { (Graduated, Dec } \\
06 \text { ) } \\
\end{array}$ & $\begin{array}{l}\text { Resin infusion } \\
\text { processing of } \\
\text { laminated } \\
\text { composites }\end{array}$ & $\begin{array}{l}\text { Private Sector - } \\
\text { Civil structures } \\
\text { company }\end{array}$ \\
\hline 2 & Carol Ochoa & $\begin{array}{l}\text { Materials Science } \\
\text { \& Engineering, } \\
\text { PhD } \\
\text { (Graduated, May } \\
\text { 2010) } \\
\end{array}$ & $\begin{array}{l}\text { Metal } \\
\text { thermoplastic } \\
\text { hybrid } \\
\text { composites }\end{array}$ & $\begin{array}{l}\text { Fenner Belts, } \\
\text { Pennsylvania }\end{array}$ \\
\hline 3 & $\begin{array}{l}\text { Balaji } \\
\text { Venkatachari }\end{array}$ & $\begin{array}{l}\text { Mechanical } \\
\text { Engineering, PhD }\end{array}$ & $\begin{array}{l}\text { Simulation of } \\
\text { flow fields in } \\
\text { automotive } \\
\text { bodies }\end{array}$ & $\begin{array}{l}\text { Private sector, } \\
\text { Huntsville, } \\
\text { Alabama }\end{array}$ \\
\hline 4 & $\begin{array}{l}\text { Amol } \\
\text { Vaidya }\end{array}$ & $\begin{array}{l}\text { Civil \& } \\
\text { Environmental } \\
\text { Engineering, PhD } \\
\text { (Graduated, May } \\
\text { 09) } \\
\end{array}$ & $\begin{array}{l}\text { Sandwich } \\
\text { construction for } \\
\text { crashworthiness } \\
\text { of automotive } \\
\text { applications } \\
\end{array}$ & $\begin{array}{l}\text { Owens Corning, } \\
\text { Granville, Ohio }\end{array}$ \\
\hline 5 & $\begin{array}{l}\text { Lakshya } \\
\text { Deka }\end{array}$ & $\begin{array}{l}\text { Materials Science } \\
\text { \& Engineering, } \\
\text { PhD } \\
\text { (Graduated Dec 08) }\end{array}$ & $\begin{array}{l}\text { LS-DYNA } \\
\text { modeling of } \\
\text { thermoplastic } \\
\text { composites } \\
\end{array}$ & $\begin{array}{l}\text { Whirlpool, } \\
\text { Michigan }\end{array}$ \\
\hline 6 & Satya Vaddi & $\begin{array}{l}\text { Materials Science } \\
\text { \& Engineering, MS } \\
\text { (Graduated May } \\
\text { 09) } \\
\end{array}$ & $\begin{array}{l}\text { Fire behavior of } \\
\text { thermoplastic } \\
\text { composites }\end{array}$ & $\begin{array}{l}\text { Private Sector, } \\
\text { Company in } \\
\text { New Jersey }\end{array}$ \\
\hline 7 & Felipe Pira & $\begin{array}{l}\text { Materials Science } \\
\text { \& Engineering, MS }\end{array}$ & $\begin{array}{l}\text { Process } \\
\text { Modeling of } \\
\text { Thermoplastic } \\
\text { Composites } \\
\end{array}$ & $\begin{array}{l}\text { Airbus, United } \\
\text { Kingdom }\end{array}$ \\
\hline 8 & $\begin{array}{l}\text { Leigh } \\
\text { Hudson }\end{array}$ & $\begin{array}{l}\text { Materials Science } \\
\text { \& Engineering, MS } \\
\text { (Graduating Dec } \\
\text { 09) }\end{array}$ & $\begin{array}{l}\text { Pultrusion of } \\
\text { thermoplastic } \\
\text { composite } \\
\text { elements }\end{array}$ & $\begin{array}{l}\text { Toray Carbon } \\
\text { Fibers of } \\
\text { America (Toray } \\
\text { CFA), Decatur, } \\
\text { Alabama }\end{array}$ \\
\hline 9 & $\begin{array}{l}\text { Lina } \\
\text { Herrera- }\end{array}$ & $\begin{array}{l}\text { Materials Science } \\
\text { \& Engineering, MS }\end{array}$ & $\begin{array}{l}\text { Banana Fiber } \\
\text { Composites for }\end{array}$ & $\begin{array}{l}\text { Pursuing } \mathrm{PhD} \text { at } \\
\text { Georgia Tech, }\end{array}$ \\
\hline
\end{tabular}




\begin{tabular}{|c|c|c|c|c|}
\hline & Estrada & $\begin{array}{l}\text { (Graduated, May } \\
\text { 09) }\end{array}$ & $\begin{array}{l}\text { automotive } \\
\text { applications }\end{array}$ & Atlanta \\
\hline 10 & $\begin{array}{l}\text { Danila } \\
\text { Kaliberov }\end{array}$ & $\begin{array}{l}\text { Materials Science } \\
\text { \& Engineering; MS } \\
\text { (Current) }\end{array}$ & $\begin{array}{l}\text { Threaded long } \\
\text { fiber } \\
\text { thermoplastic } \\
\text { composites }\end{array}$ & $\begin{array}{l}\text { Undergraduate } \\
\text { GATE scholar - } \\
\text { Working on } \\
\text { PhD at UAB }\end{array}$ \\
\hline 11 & $\begin{array}{l}\text { Michael } \\
\text { Magrini }\end{array}$ & $\begin{array}{l}\text { Materials Science } \\
\text { \& Engineering, MS } \\
\text { (Graduated BS } \\
\text { May 08; continued } \\
\text { as graduate student) }\end{array}$ & $\begin{array}{l}\text { Impact } \\
\text { response of } \\
\text { long fiber and } \\
\text { laminated } \\
\text { thermoplastic } \\
\text { composite } \\
\text { materials }\end{array}$ & $\begin{array}{l}\text { Undergraduate } \\
\text { GATE scholar - } \\
\text { Working on } \\
\text { PhD at UAB }\end{array}$ \\
\hline 12 & Melike Onat & $\begin{array}{l}\text { Interdisciplinary } \\
\text { Engineering, PhD } \\
\text { (Joined Dec 09) }\end{array}$ & $\begin{array}{l}\text { Thermoplastic } \\
\text { pultrusion with } \\
\text { hot-melt } \\
\text { impregnated } \\
\text { tapes }\end{array}$ & $\begin{array}{l}\text { Interdisciplinary } \\
\text { Engineering } \\
\text { GATE scholar - } \\
\text { Working on } \\
\text { PhD at UAB }\end{array}$ \\
\hline 13 & Aaron Siegel & $\begin{array}{l}\text { Materials Science \& } \\
\text { Engineering, } \\
\text { PhD } \\
\text { Joined Fall } 2010\end{array}$ & $\begin{array}{l}\text { Energy } \\
\text { absorbing } \\
\text { compounded } \\
\text { thermoplastic } \\
\text { foams for } \\
\text { enhanced } \\
\text { crashworthiness }\end{array}$ & $\begin{array}{l}\text { GATE scholar, } \\
\text { working on MS } \\
\text { at UAB }\end{array}$ \\
\hline 14 & Peter Barfknecht & $\begin{array}{l}\text { Materials } \\
\text { Science/Biomedical } \\
\text { Engineering, PhD, } \\
\text { Joined Fall } 2009\end{array}$ & $\begin{array}{l}\text { Carbon fiber } \\
\text { sizing and } \\
\text { liquid molding } \\
\text { of reactive } \\
\text { thermoplastics }\end{array}$ & $\begin{array}{l}\text { GATE scholar, } \\
\text { working on MS } \\
\text { at UAB }\end{array}$ \\
\hline 15 & Nsiande Mfala & $\begin{array}{l}\text { Materials Science \& } \\
\text { Engineering, MS } \\
\text { Joined Spring } 2011\end{array}$ & $\begin{array}{l}\text { Nanostructured } \\
\text { kenaf and } \\
\text { banana fiber } \\
\text { thermoplastic } \\
\text { composites for } \\
\text { automotive } \\
\text { applications }\end{array}$ & $\begin{array}{l}\text { Undergraduate } \\
\text { scholar, } \\
\text { Working on MS } \\
\text { at UAB }\end{array}$ \\
\hline 16 & $\begin{array}{l}\text { Benjamin } \\
\text { Geiger- } \\
\text { Willis }\end{array}$ & $\begin{array}{l}\text { Materials Science \& } \\
\text { Engg. MS joining } \\
\text { Summer } 2011\end{array}$ & $\begin{array}{l}\text { High strain rate } \\
\text { impact of } \\
\text { thermoplastic } \\
\text { composites and } \\
\text { foams for } \\
\text { crashworthiness }\end{array}$ & $\begin{array}{l}\text { Undergraduate } \\
\text { GATE scholar, } \\
\text { working on PhD } \\
\text { at UAB }\end{array}$ \\
\hline
\end{tabular}


Table 2. GATE IMPACT FOR GRADUATE STUDIES PIPELINE: LIST OF GATE UNDERGRADUATE STUDENT PIPELINE (INCLUDING HIGH SCHOOL STUDENTS) TO GRADUATE SCHOOL

\begin{tabular}{|c|c|c|c|c|}
\hline & Name & $\begin{array}{l}\text { Standing when } \\
\text { working in the } \\
\text { GATE } \\
\text { program }\end{array}$ & Topic & $\begin{array}{l}\text { Where } \\
\text { Placed/What } \\
\text { they are doing? }\end{array}$ \\
\hline 1 & $\begin{array}{l}\text { Malina } \\
\text { Panda }\end{array}$ & $\begin{array}{l}\text { Senior, } \\
\text { Materials } \\
\text { Science \& } \\
\text { Engineering } \\
\text { (Graduated, } \\
\text { May 07) }\end{array}$ & $\begin{array}{l}\text { Development of } \\
\text { hot-melt } \\
\text { impregnated } \\
\text { materials }\end{array}$ & $\begin{array}{l}\text { Private Sector, } \\
\text { Atlanta, GA }\end{array}$ \\
\hline 2 & $\begin{array}{l}\text { Daniel } \\
\text { Kaliberov }\end{array}$ & $\begin{array}{l}\text { Junior, } \\
\text { Materials } \\
\text { Science \& } \\
\text { Engineering }\end{array}$ & $\begin{array}{l}\text { Vibration testing } \\
\text { of long fiber } \\
\text { thermoplastic } \\
\text { composites }\end{array}$ & $\begin{array}{l}\text { Went on to } \\
\text { Graduate School } \\
\text { as GATE scholar }\end{array}$ \\
\hline 3 & $\begin{array}{l}\text { Michael } \\
\text { Magrini }\end{array}$ & $\begin{array}{l}\text { Senior, } \\
\text { Materials } \\
\text { Science \& } \\
\text { Engineering }\end{array}$ & $\begin{array}{l}\text { Impact response of } \\
\text { long fiber and } \\
\text { laminated } \\
\text { thermoplastic } \\
\text { composite } \\
\text { materials }\end{array}$ & $\begin{array}{l}\text { Joined UAB as } \\
\text { GATE scholar }\end{array}$ \\
\hline 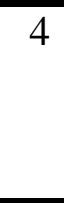 & $\begin{array}{l}\text { Michael } \\
\text { Entz }\end{array}$ & $\begin{array}{l}\text { Senior, } \\
\text { Materials } \\
\text { Engineering }\end{array}$ & $\begin{array}{l}\text { Impact analysis of } \\
\text { laminated } \\
\text { composites }\end{array}$ & $\begin{array}{l}\text { Went to graduate } \\
\text { studies at Univ. } \\
\text { of North } \\
\text { Carolina }\end{array}$ \\
\hline 5 & V. Ameya & $\begin{array}{l}\text { Senior, Auburn } \\
\text { University }\end{array}$ & $\begin{array}{l}\text { Self reinforced } \\
\text { polypropylene } \\
\text { studies }\end{array}$ & $\begin{array}{l}\text { Senior, Auburn } \\
\text { University, } \\
\text { Chemical Engg. }\end{array}$ \\
\hline 6 & $\begin{array}{l}\text { Hadeel } \\
\text { Abdelmajeed }\end{array}$ & $\begin{array}{l}\text { Senior, } \\
\text { Materials } \\
\text { Science \& } \\
\text { Engineering } \\
\end{array}$ & $\begin{array}{l}\text { Thermoforming } \\
\text { processing of } \\
\text { laminated } \\
\text { composites }\end{array}$ & $\begin{array}{l}\text { BAE Systems, } \\
\text { Phoenix, } \\
\text { Arizona }\end{array}$ \\
\hline 7 & $\begin{array}{l}\text { Walter } \\
\text { Malone }\end{array}$ & $\begin{array}{l}\text { Sophomore, } \\
\text { Materials } \\
\text { Science \& } \\
\text { Engineering }\end{array}$ & $\begin{array}{l}\text { Sandwich panel } \\
\text { construction for } \\
\text { automotive floor } \\
\text { boards }\end{array}$ & $\begin{array}{l}\text { Hanna Steels, } \\
\text { Birmingham, AL }\end{array}$ \\
\hline 8 & Victor Long & $\begin{array}{l}\text { Sophomore, } \\
\text { Materials } \\
\text { Science \& } \\
\text { Engg. }\end{array}$ & $\begin{array}{l}\text { Compression after } \\
\text { impact of layered } \\
\text { materials }\end{array}$ & Raytheon, AZ \\
\hline
\end{tabular}




\begin{tabular}{|c|c|c|c|c|}
\hline 9 & $\begin{array}{l}\text { David } \\
\text { Sexton }\end{array}$ & $\begin{array}{l}\text { Junior, } \\
\text { Materials } \\
\text { Science \& } \\
\text { Engineering }\end{array}$ & $\begin{array}{l}\text { Carbon fiber } \\
\text { thermoplastic } \\
\text { impregnation }\end{array}$ & $\begin{array}{l}\text { Southern } \\
\text { Company } \\
\text { Services, AL }\end{array}$ \\
\hline 10 & $\begin{array}{l}\text { Saptarshi } \\
\text { Vichare }\end{array}$ & $\begin{array}{l}\text { Junior, } \\
\text { Mechanical } \\
\text { Engineering }\end{array}$ & $\begin{array}{l}\text { Carbon fiber } \\
\text { thermoplastic } \\
\text { impregnation }\end{array}$ & $\begin{array}{l}\text { Pursuing degree } \\
\text { in Industrial Art, } \\
\text { Washington, DC }\end{array}$ \\
\hline 11 & $\begin{array}{l}\text { Benjamin } \\
\text { Rice }\end{array}$ & $\begin{array}{l}\text { Senior, Rhodes } \\
\text { College, } \\
\text { Memphis } \\
\text { (Summer 08) }\end{array}$ & $\begin{array}{l}\text { Compression after } \\
\text { impact of E- } \\
\text { glass/vinyl ester } \\
\text { composites }\end{array}$ & $\begin{array}{l}\text { Pursuing } \\
\text { graduate studies } \\
\text { at Carnegie } \\
\text { Mellon Univ. }\end{array}$ \\
\hline 12 & $\begin{array}{l}\text { Khongor } \\
\text { Jaamiyana }\end{array}$ & $\begin{array}{l}\text { Senior, } \\
\text { Colorado State } \\
\text { Univ (Summer } \\
\text { 08) }\end{array}$ & $\begin{array}{l}\text { Low velocity } \\
\text { impact response of } \\
\text { Carbon SMC }\end{array}$ & $\begin{array}{l}\text { Joined UAB as } \\
\text { GATE scholar }\end{array}$ \\
\hline 13 & $\begin{array}{l}\text { Alex } \\
\text { Johnson }\end{array}$ & $\begin{array}{l}\text { Sophomore, } \\
\text { Auburn } \\
\text { University }\end{array}$ & $\begin{array}{l}\text { Carbon fiber } \\
\text { impregnation and } \\
\text { characterization }\end{array}$ & $\begin{array}{l}\text { Junior, Auburn } \\
\text { University }\end{array}$ \\
\hline 14 & $\begin{array}{l}\text { Krishane } \\
\text { Suresh }\end{array}$ & $\begin{array}{l}\text { Freshmen, Oak } \\
\text { Mountain High } \\
\text { School }\end{array}$ & $\begin{array}{l}\text { Long fiber } \\
\text { thermoplastics } \\
\text { processing }\end{array}$ & $\begin{array}{l}\text { Sophomore, } \\
\text { Auburn } \\
\text { University }\end{array}$ \\
\hline 15 & $\begin{array}{l}\text { Amber } \\
\text { Williams }\end{array}$ & $\begin{array}{l}\text { Jefferson } \\
\text { County } \\
\text { Baccalaureate }\end{array}$ & $\begin{array}{l}\text { Pultruded } \\
\text { composites } \\
\text { characterization }\end{array}$ & $\begin{array}{l}\text { Senior, Jefferson } \\
\text { County } \\
\text { Baccalaureate } \\
\text { school }\end{array}$ \\
\hline 16 & $\begin{array}{l}\text { Anshul } \\
\text { Bansal }\end{array}$ & $\begin{array}{l}\text { Alabama School } \\
\text { of Fine Arts }\end{array}$ & $\begin{array}{l}\text { Fuel cell demo and } \\
\text { composite bipolar } \\
\text { plates }\end{array}$ & Senior, ASFA \\
\hline 17 & $\begin{array}{l}\text { Sueda } \\
\text { Baldwin }\end{array}$ & $\begin{array}{l}\text { Junior, } \\
\text { Materials } \\
\text { Science \& } \\
\text { Engg. }\end{array}$ & $\begin{array}{l}\text { Long fiber } \\
\text { thermoplastic fiber } \\
\text { orientation studies }\end{array}$ & $\begin{array}{l}\text { Private sector, } \\
\text { Gainsville, } \\
\text { Florida }\end{array}$ \\
\hline 18 & William Warner & $\begin{array}{l}\text { Junior, Materials } \\
\text { Science \& Engg. }\end{array}$ & $\begin{array}{l}\text { Nondestructive } \\
\text { evaluation of defects } \\
\text { in sandwich } \\
\text { composites }\end{array}$ & $\begin{array}{l}\text { Senior, UAB } \\
\text { Materials } \\
\text { Engineering }\end{array}$ \\
\hline 19 & Theresa Bayush & $\begin{array}{l}\text { Senior, Materials } \\
\text { Science \& Engg. }\end{array}$ & $\begin{array}{l}\text { Nanostructured } \\
\text { banana fibers } \\
\text { composites } \\
\end{array}$ & $\begin{array}{l}\text { Joined UAB as } \\
\text { GATE scholar }\end{array}$ \\
\hline 20 & $\begin{array}{l}\text { Benjamin } \\
\text { Geiger-Willis }\end{array}$ & $\begin{array}{l}\text { Seniors, Materials } \\
\text { Science \& Engg. }\end{array}$ & $\begin{array}{l}\text { Design and } \\
\text { Construction of a Split } \\
\text { Hopkinson Pressure } \\
\text { Bar for high strain rate } \\
\text { impact testing of } \\
\text { materials }\end{array}$ & $\begin{array}{l}\text { Joined UAB as } \\
\text { GATE scholar }\end{array}$ \\
\hline
\end{tabular}




\section{E. GATE COURSES}

The following courses were developed offered as part of the UAB GATE program

MSE 634/734: Design \& Manufacturing Technologies for Automotive Applications Recent advances in lightweight materials technologies relevant to automotive design and manufacturing. The course emphasizes materials, design, manufacturing and testing aspects of automotive components, products and systems utilizing plastics, composites, sheet metal and metal castings. State of the art SMC, BMC, LFT, GMTex, carbon fiber and other advanced materials are emphasized. Fuel efficiency, CAFÉ standards and recycling aspects are covered. Laboratory experience integrated with course.

\section{MSE 635/735: Advanced Composite Mechanics}

Micro- and macro-mechanics of composite materials, lamination theory along with use of lamination software, elastic constants and strength, failure criteria, hygrothermal effects, design of composites for static, impact and fatigue loads, case studies in design, mechanics of discontinuous, continuous and sandwich composites.

\section{MSE 667/767: Process Modeling and Simulation for Lightweight Materials}

Mechanics and computer methods for manufacturing processes of metals, polymers /plastics, composites and ceramics. Processes to be covered include: metal forming -(e.g., forging, rolling, extrusion, sheet metal forming, drawing), metal removal (machining, grinding), plastics and composites processes (e.g., injection molding, resin transfer molding and compression molding), and ceramics processing (e.g., powder metallurgy). Computer experience integrated with course.

\section{MSE 490/590: Nanomaterials for Automotive Applications}

Basics of nanoclays, nanotubes, nanoplatelets, synthesis and processing, dispersion and agglomeration, nano characterization tools, rheology and thermomechanical response, nanocomposites, application of $\mathrm{x}$-ray and electron diffraction, light, electron and atomic force microscopy to crystal structure and morphology of nanomaterials. Applications of nano in automotive. Laboratory experience integrated with course.

\section{MSE/ME 533: Nondestructive Evaluation}

Nondestructive evaluation (NDE) of metals, polymer, composite, ceramic materials, components and structures. The detection, location, measurement, evaluation of discontinuities, defects, other imperfections for assessment of structural integrity, properties, and composition. Laboratory experience is integrated in the course for each of the NDE technique.

\section{ME/MSE/CEE 690/790: Mechanical Characterization \& Performance Evaluation of Advanced Lightweight Materials}

Testing and test methods for advanced metals and composites., ASTM, SAE, ISO and International standards for static tensile, flexure, compression, interlaminar shear, dynamic fatigue, vibration, impact, crashworthiness, high strain rate effects, failure and fracture mechanisms, microscopic characterization, Laboratory experience integrated with course. 
BME/MSE/CE: Optimized Lightweight Material Designs for Improved Protection Biomechanics of injury, critical load paths, modeling and simulation of biomechanical systems, injury protection designs of side body, and frontal/rear panels, structure-body-interactions. Materials response and strain-rate effects. Laboratory experience integrated with course.

\section{Students Impact by UAB GATE through COURSE offerings}

\begin{tabular}{|c|c|c|}
\hline Courses & When and Where Held & $\begin{array}{c}\text { Number of Student } \\
\text { Participants }\end{array}$ \\
\hline $\begin{array}{c}\text { Design and Manufacturing } \\
\text { for Automotive Materials } \\
\text { (Graduate, MS/PhD level), } \\
\text { MSE 634/734 }\end{array}$ & $\begin{array}{l}\text { Summer 2006, Summer } \\
2009 \text { and Summer } 2011 \\
\text { UAB campus }\end{array}$ & 45 \\
\hline $\begin{array}{l}\text { Process Modeling and } \\
\text { Simulation for Automotive } \\
\text { Applications (Graduate, } \\
\text { MS/PhD level) } \\
\text { MSE 667/767 }\end{array}$ & $\begin{array}{l}\text { Fall 2006, Fall 2008, Fall } \\
2010 \\
\text { UAB campus }\end{array}$ & 32 \\
\hline $\begin{array}{l}\text { Advanced Composite } \\
\text { Mechanics }\end{array}$ & $\begin{array}{l}\text { Spring 2006, Fall 2007, } \\
\text { Spring } 2010\end{array}$ & 42 \\
\hline $\begin{array}{c}\text { Nanomaterials for } \\
\text { Automotive Applications } \\
\text { (BS Senior/MS) } \\
\text { MSE 490/590B } \\
\end{array}$ & $\begin{array}{l}\text { Summer 2007, Summer } \\
2009 \text { and Summer } 2011\end{array}$ & 60 \\
\hline Nondestructive Evaluation & $\begin{array}{l}\text { Fall 2005, Fall 2007, Fall } \\
\text { 2009, Spring 2011 }\end{array}$ & 60 \\
\hline $\begin{array}{l}\text { Mechanical testing and } \\
\text { failure }\end{array}$ & $\begin{array}{l}\text { Fall 2006, Fall 2008, Fall } \\
2010\end{array}$ & 44 \\
\hline Crash and Injury Prevention & $\begin{array}{l}\text { Summer 2007, Summer } \\
2009\end{array}$ & 22 \\
\hline TOTAL & & 303 \\
\hline
\end{tabular}

\section{AUTOMOTIVE CERTIFICATE (GATE Graduate Fellows)}

"GATE Certificate" was issued at the department level for GATE graduate fellows

1. Met the requirements for a graduate degree

2. Completed a minimum of 4 GATE courses

3. Completed a research project tied to the automotive or transportation area

\section{AUTOMOTIVE CERTIFICATE (Undergraduate GATE fellows)}

A participation certificate was issued to undergraduate students who participate in GATE projects or work on senior design related to automotive projects 


\section{F. PUBLICATIONS BY GATE FELLOWS}

F1. The following papers have been presented/published in the reporting period by the GATE fellows/research:

1) Structural Thermoplastics for Automotive and Transportation., U.K.Vaidya, National Corrosion Engineers Conference (NACE 2007), Nashville, TN March 11-15, 2007.

2) Fire Response of Thermoplastic Composites., Satya Vaddi, S. Pillay and U.K.Vaidya, UAB Graduate Student Research Day, February 28-29, 2007.

3) Finite Element Analysis of Hardwire/Thermoplastic Composites., Carol Ochoa and U.K.Vaidya, UAB Graduate Student Research Day, February 28-29, 2007.

4) Structural Thermoplastics for Automotive Applications., U.K.Vaidya., SAMPE 2007, Baltimore, MD, June 1-5, 2007.

5) Performance Evaluation of Continuous Fiber Thermoplastics., S. Vaidya, J. Serrano and Balaji T., MAESC 2007, Oxford, Mississippi, May 2007.

6) Process simulation, design and manufacturing of a long fiber thermoplastic composite for mass transit application., K. Balaji Thattaiparthasarathy, S. Pillay, H. Ning, U.K. Vaidya, Composites Part A, Applied Science \& Manufacturing, Vol. 39, Issue 9, Sep 2008, pp. 1512-1521.

7) Rheological Characterization of Long Fiber Thermoplastics - Effect of Temperature, Fiber Length and Weight Fraction, K. Balaji Thattaiparthasarathy, Selvum Pillay, and Uday K. Vaidya., Composites Part A: Applied Science \& Engineering, Sep 2008.

8) Damage Tolerance Enhancement using Continuous Fiber Reinforcements Co-Molded with Long Fiber Reinforced Thermoplastics., U.K.Vaidya, K. Balaji Thattaiparthasarathy, S. Pillay., SPE Automotive Composites Conference., Sep 16-18, 2008 (CD-ROM Proceedings).

9) Banana Fiber Composites for Automotive and Transportation Applications., Lina-Herrera Estrada, U.K.Vaidya and S. Pillay., SPE Automotive Composites Conference., Sep 1618, 2008 (CD-ROM Proceedings).

10) Processing \& Characterization of Continuous Fiber Reinforcements Co-molded with Long Fiber Reinforced Thermoplastics., K. Balaji Thattaiparthasarathy and U.K.Vaidya, SAMPE 2008, Long Beach, CA May 1-5, 2008.

11) T. Balaji, U.K.Vaidya, S. Pillay and H. Ning., Design and Development of LFT Battery Access Door., Composites A: Applied Science \& Manufacturing, Feb 2008.

12) T. Balaji, U.K.Vaidya, Processing and Characterization of Co-Molded Continuous Fiber Reinforcement with Long Fiber Thermoplastics, SAMPE Long Beach, May 2008.

13) Naiyu Sun, Burton Patterson, Jaakko Suni, Eider Simielli, Hasso Weiland, Puja Kadolkar, Craig Blue, and Gregory Thompson, "Heating Rate Effect on Microstructure Evolution during Annealing of Twin Roll Cast AA3105," in Aluminum Wrought Products for Automotive, Packaging, and other Applications, Eds. S. Das, G. Jha, Z. Li, T. Zhai, and J. Liu, TMS, pp. 119-124, 2006.

14) U. K.Vaidya., Fire Response of Thermoplastic Composites., Managing Corrosion with Polymers, CD-ROM Proceedings, NACE International Corrosion 2008.

15) Derrick Dean, Apollo M. Obore, Sylvester Richmond and Elijah Nyairo, "Multiscale Fiber-Reinforced Nanocomposites: Synthesis, Processing and Properties," Composites Science and Technology 66 (2006) 2135-2142. 
16) Haibin Ning, Gregg M. Janowski, Uday K. Vaidya, and George Husman., Thermoplastic sandwich structure design and manufacturing for the body panel of mass transit vehicle, Composite Structures, June 2009.

17) P. Scarber, Jr., C.E. Bates, and J. Griffin, "Effects of Mold and Binder Formulations on Gas Evolution When Pouring Aluminum Castings", 2006 AFS Transactions

18) S.D Bartus, C.A.Ulven, and U.K.Vaidya., Design and Development of Long Fiber Thermoplastic Bus Seat, Journal of Thermoplastic Composite Materials, Vo. 9, No. 2, pp. 131-154, March 2006.

19) U.K.Vaidya and G. Husman., Thermoplastic Composites for Mass Transit Applications., American Composites Manufacturer's Association (ACMA), Birmingham, AL Feb 08-09, 2006

20) Numerical Model to Predict the Limiting Bond Strength in a Metal Thermoplastic Composite., Carol Ochoa and Uday Vaidya., SAMPE 2008, Long Beach, CA May 1-5, 2008.

21) Impact Response of Three Dimensional Multifunctional Sandwich Composite., A.S.Vaidya, U.K.Vaidya, N.Uddin., Materials Science and Engineering-Part A Volume 472, Issues 1-2, 15 January 2008, Pages 52-58.

22) Performance of space accessible sandwich composite under the static compression and flexural loading., A.S.Vaidya, U.Vaidya, N.Uddin., Polymer and Polymer Matrix Composites, Dec 2008.

23) Vibration response of 3-D space accessible sandwich composites., A.S.Vaidya, U.Vaidya, N.Uddin., Journal of Reinforced Plastics and Composites. July 2009.

24) Design and Development of Thermoplastic Composite Roof Door for Mass Transit Bus., Haibin Ning, S. Pillay and U.K.Vaidya., Materials and Design, June 2008.

25) Processing of Reinforced Thermoplastic Composite Materials., U.K.Vaidya and K.K.Chawla, International Journal of Materials Review, June 2008.

26) The Process and Microstructure Modeling of Long-Fiber Thermoplastic Composites., U.K. Vaidya, K.K. Chawla, K. Balaji Thattaiparthasarathy, and A. Goel., Journal of Materials., April 2008, pp. 43-49.

27) Kulkarni, R.R., Chawla, K.K.; Vaidya, U.K.; Koopman, M.C.; Characterization of long fiber thermoplastic/metal laminates., Journal of Materials Science, v 43, n 13, July, 2008, p 4391-4398.

28) Carol Ochoa and U.K.Vaidya., Metal-fiber thermoplastic laminate: Interface studies and characterization; Polymers and Polymer Composites., Jan 2010..

29) U.K.Vaidya, S. Pillay, H. Ning, Balaji, T., Development of Colored Inorganic Pigmented Long Fiber Reinforced Thermoplastics., SAMPE Seattle, May 2010.

30) U.K.Vaidya, Balaji Thattai, D.Kaliberov, S. Pillay and H. Ning., Recycled Long Fiber Thermoplastic Composites for Transportation Applications., SAMPE Seattle, May 2010.

31) U.K.Vaidya, A. Goel and K.K. Chawla., Fatigue Response of Long Fiber Reinforced Thermoplastics., SPE Automotive Composites Conference., Sep 2009 (CD-ROM Proceedings).

32) Vaidya U.K et al., Application Development with Thermoplastic Composites for Automotive and Mass Transit, Invited Talk, ICC-CFT 2011, Indian Institute of Science, Bangalore, India, Jan 4-7, 2011.

33) Carol Ochoa and U.K.Vaidya., Interfacial Shear Strength in a Metal-Thermoplastic Composite, Polymers and Polymer Composites., Vol. 18, No. 7, pp. 369-380, 2010. 
34) Carol Ochoa and U.K.Vaidya., Mechanisms of Interfacial Adhesion In Metal-Polymer Composites. Composites Science and Technology Journal (Accepted, In-press).

35) U.K.Vaidya, Balaji, T, S. Pillay, H. Ning., Colored Inorganic Pigmented Long Fiber Reinforced Thermoplastics., SAMPE Seattle, May 2010.

36) U.K.Vaidya, Balaji Thattai, D.Kaliberov, S. Pillay and H. Ning., Recycled Long Fiber Thermoplastic Composites for Transportation Applications. SAMPE Seattle, May 2010.

37) John Smith and U.K.Vaidya, Progressive forming of thermoplastic composite laminates., SPE Automotive Composites Conference \& Exposition (ACCE 2010), Troy, MI, Sep 1516, 2010, CD-ROM proceedings.

38) Nanostructured banana fibers/biopolymer composites for transportation., Nsiande Mfala and Theresa Bayush., SPE Automotive Composites Conference \& Exposition (ACCE 2010), Troy, MI, Sep 15-16, 2010, CD-ROM proceedings.

39) Utilization of heavy truck industry scrap for production of long fiber thermoplastic recycled composites for use in transportation., Ameya V. and Balaji T., Auburn University, SPE Automotive Composites Conference \& Exposition (ACCE 2010), Troy, MI, Sep 1516, 2010, CD-ROM proceedings.

\section{F2. Book}

Dr. Vaidya, the GATE PI completed a book on Composites for Automotive, Truck and Mass Transit: Materials, Design, Manufacturing

This technical monograph provides a comprehensive explanation of how advanced composite materials, including FRPs, reinforced thermoplastics and others, are designed, manufactured and utilized in exterior, interior, under-the-hood structural, semi-structural and non-structural components in passenger cars, trucks, and mass transit vehicles. The book clarifies how the material properties of composites can be optimized to decrease weight, expand design options, improve crashworthiness, and reduce fuel consumption in response to CAFÉ and other regulations.

\section{Table of Contents}

1. Introduction, 2. Thermoset and Thermoplastic Polymer Resins, Additives, Sandwich Cores, 3. Reinforcements for Automotive and Transportation, 4. Intermediate Material Forms, 5. Discontinuous Reinforcement-Based Processes (GMT, LFT, SMC), 6. Continuous Fiber Reinforcement Based Processes, 7. Mechanics and Design Tips, 8. Composite Manufacturing Process Analysis, 9. Carbon Fiber, 10. Performance Cars, 11. Heavy Trucking and Mass Transit, 12. Joining and Adhesives.,13. Bio-, Recycling and Environmental Aspects, 14. Summary

The UAB work on light weighting of mass transit systems appeared in the Composites Technology magazine that has international circulation in the composites industries, see Figure $1 .$. 

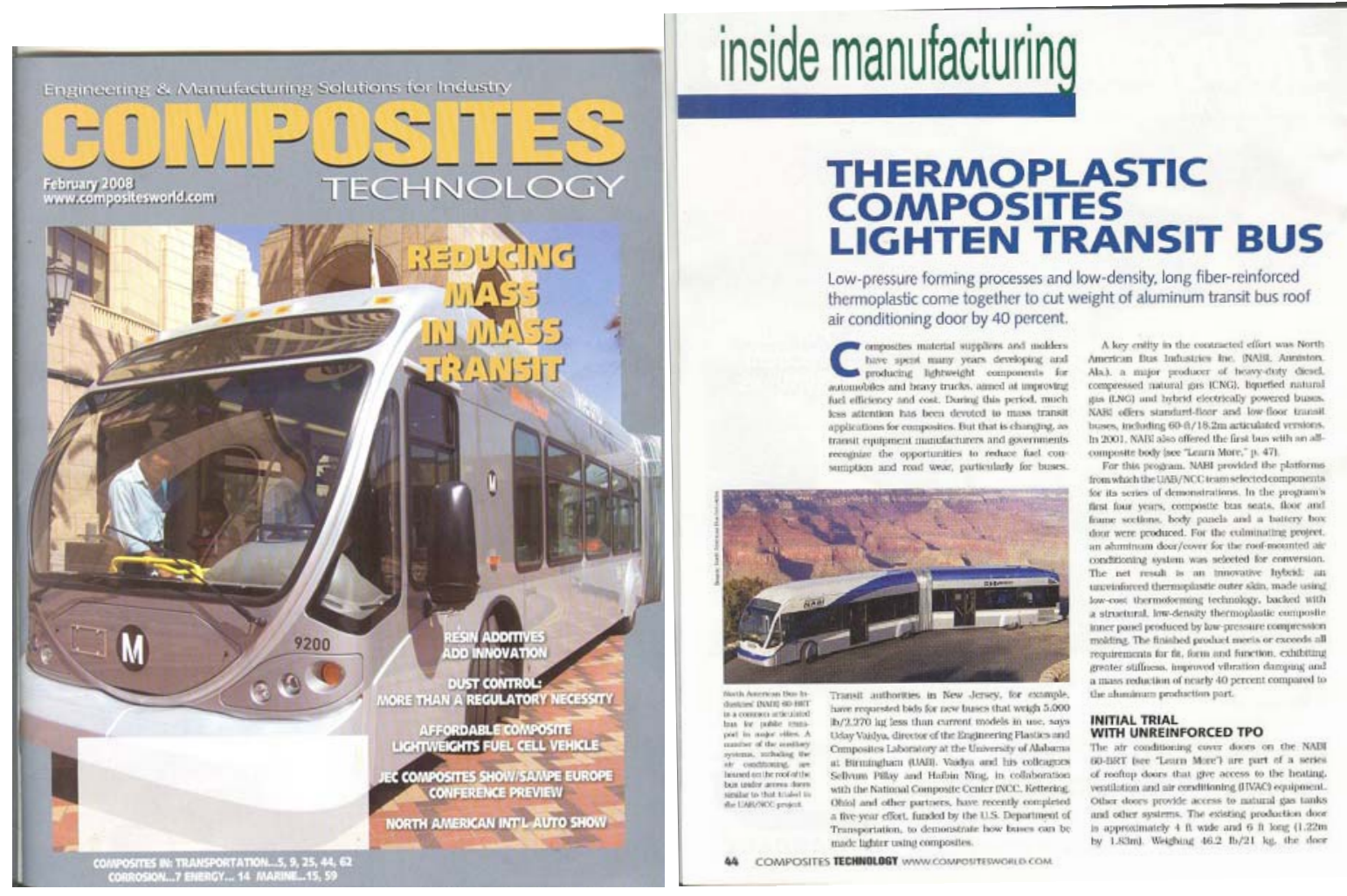

Figure 1. UAB GATE researchers work featured in Composites Technology Magazine.

\section{G. INTELLECTUAL PROPERTY/PATENT}

1) Design and Manufacturing of Long Fiber Thermoplastic Composite Access Doors for Mass Transit, Light Rail and Other Transportation Applications (July 2007), Uday Vaidya, Haibin Ning, S. Pillay

\section{H. SUMMER STUDENT TRAINING, WORKSHOPS AND OTHER TRAINING ACTIVIES}

Several workshops were conducted for training GATE fellows and other graduate as well as undergraduate students in collaborating institutions on composites processing, characterization/test methods and modeling. Over 300 students have benefited from these workshop offerings. These workshops are listed below:

- Metals casting and lost foam technology (Dr. Robin Griffin, Dr. Alan Druschitz), Fig 2, Jan 2006

- Composites Hand Lay-up and Thermoforming (Drs. Selvum Pillay, Uday Vaidya), Fig. 3., March 2006.

- Extrusion-compression molding of long fiber thermoplastics. Students were exposed to material selection, material usage, and operation of the plasticator and production of high quality long fiber thermoplastic composite parts. (Drs. Pillay, Ning), Fig. 4, June 2006

- Characterization for static and dynamic properties - tensile, compression, flexure, interlaminar shear, static indentation, low velocity and high velocity impact. 
- Polymer rheology measurements - DSC, DMA, TGA and FTIR (Dr. Derrick Dean), Fig.4

- Modeling and simulation - Viscous fiber flow modeling, finite element analysis (Dr. Haibin Ning)

- Advanced Green Composites Workshop (Drs. Vaidya, Pillay), June 2009.

- Lightweight Metals Casting Workshop, Jan 2007

- Advanced Composites for Automotive - Materials and Manufacturing, March 2007 (Ning, Thattai, Andrews, Pillay, Vaidya).

- Advanced Composites Processing and Testing Workshop, (June 2007, Ning and Thattai)
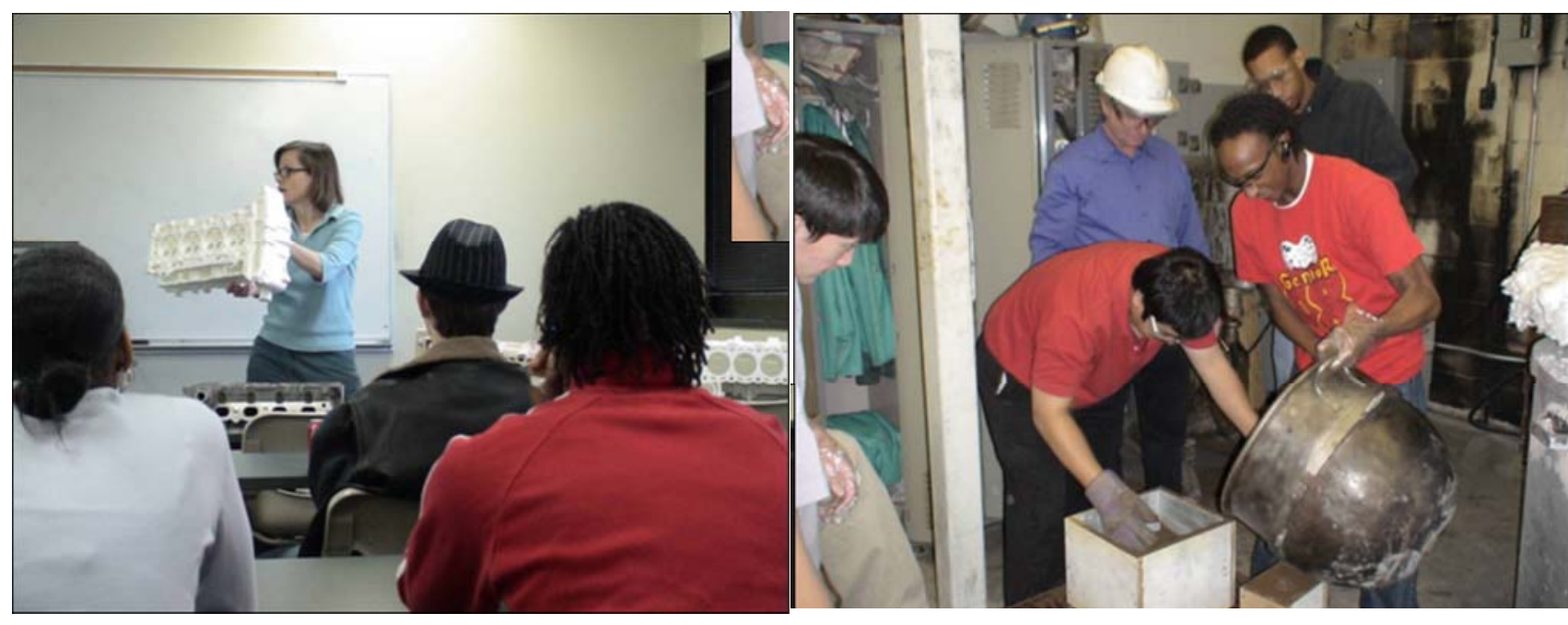

Figure 2. Metals casting GATE workshop conducted by Drs. Robin Griffin and Alan Druschitz. Attendees: GATE community college institutions, 12 students of the UAB GATE program

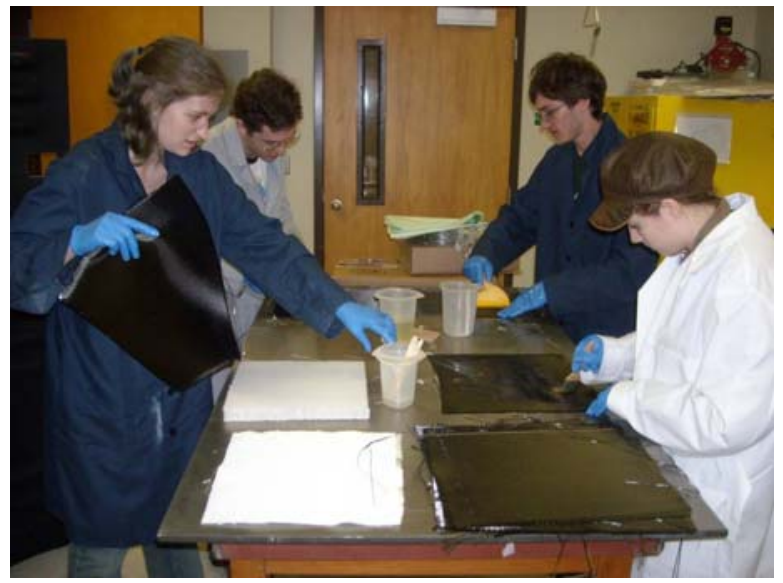

Figure 3. GATE Composites hand lay-up workshop. Attendees: Saturday Academy high school students and UAB freshmen students. 


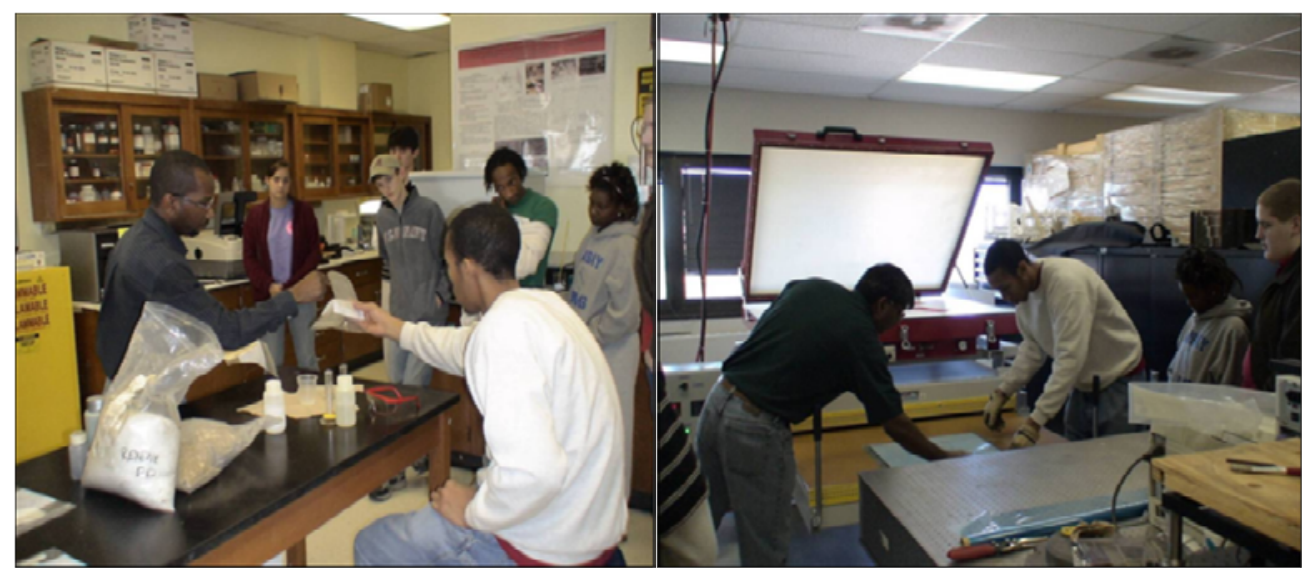

Figure 4. GATE Polymer Workshop conducted by Dr. Derrick Dean (Top), and Thermoforming Workshop conducted by Dr. Selvum Pillay (Bottom). Attendees: Saturday Academy high school students and UAB freshmen students.

- Automotive Materials and Failure Analysis, Automotive Research Association of India, (ARAI) catered to Southeast Asian industry, April 19-23, 2010 (Vaidya)

- Structural Composites in Transportation - Dedicated GATE session at the Structural Composites Conference, Birmingham, Alabama, August 24-26, 2010 (All GATE faculty).

- Workshop was held at Rhodes College, Memphis with a goal of student recruitment by training students in various aspects of composite materials applications and manufacturing. (Figure 5). Rhodes College is a source for very talented highly skilled technical students, who could consider going into the graduate program. 12 senior students attended this workshop and we plan to make this an annual event. (March 2008).

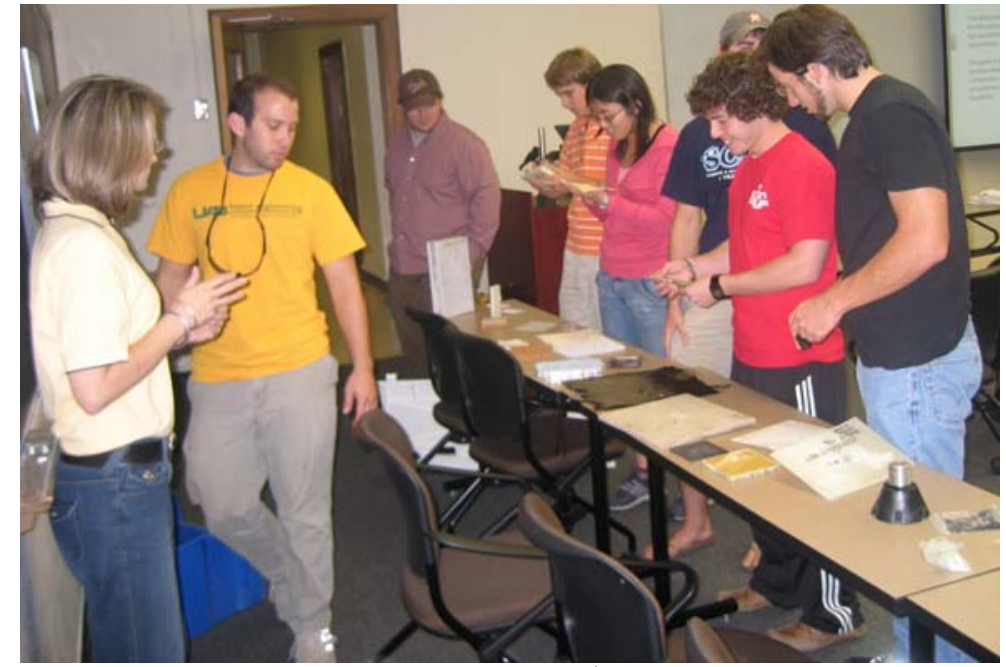

Figure 5. GATE students Leigh Hudson ( $1^{\text {st }}$ from left), Michael Magrini ( $2^{\text {nd }}$ from left), Jason Quinn ( ${ }^{\text {rd }}$ from left) accompanied by Dr. Selvum Pillay held the workshop at Rhodes College, Memphis, Tennessee. Picture shows Rhodes students working on fabricating lightweight composite plates.. 
- Extrusion-compression molding (ECM) of long fiber thermoplastics including ECM of colored inorganic compounds (CIC) in conjunction with long fibers.. Students were exposed to material selection, material usage, and operation of the plasticator and production of high quality long fiber thermoplastic composite parts. (Drs. Selvum Pillay, Haibin Ning). June 2008.

- Characterization for static and dynamic properties - tensile, compression, flexure, interlaminar shear, static indentation, low velocity and high velocity impact was offered again (Held May 2009).

- $\quad$ Polymer rheology measurements - DSC, DMA, TGA and FTIR (Dr. Derrick Dean), Aug 2008.

- Modeling and simulation - Pro/Engineer and Finite Element Analysis (Dr. Haibin Ning), Aug 2008.

- An eight-class module for EGR 111 (Freshman Engineering) was held on sheet metal design and fabrication of a sheetmetal part. 32 students in groups of 4 each, designed sheet metal parts and worked on concepts of forming limit diagram, minimum bending radius and manufacturing aspects of sheet metal parts relevant to automotive components, Sep-Oct 2008.

- $\quad$ LS-DYNA and Hypermesh modeling for automotive FEA., (Ning, Jan 2009)

- Data analysis with JMP statistical discovery software workshop, Mia Stevens, Connie Freeman, SAS Institute, Oct 7, 2010, (30+ students, 15+ faculty and researchers attended)

- SPE Automotive Composites Consortium (SPE ACCE), Sep 2010 Poster session organized and administered by GATE faculty, Troy, Michigan (Sep 2010)

- Characterization for static and dynamic properties - tensile, compression, flexure, interlaminar shear, static indentation, low velocity and high velocity impact was offered again (Held October 25-26, 2010).

- LS-DYNA and Hypermesh modeling for automotive FEA., Haibin Ning (Held November 16-30, 2010, 6 sessions)

- Session organizer on Biocomposites at International Conference on Composite Materials (ICCM 18), 2011, Jeju, South Korea

- GATE research featured at Alabama Composites Conference, August 23-26, 2010 ( 40 student posters featured GATE research).

- Birmingham Southern College (BSC) students Jan 2011) at UAB GATE center and gained experience in foam compounding processes and trials.

- Holy Family Christo Rey High School and Ramsey High School) spent Summer 2010 at UAB GATE center and were trained in processing and testing of composites. Both are underrepresented underserved community students/schools.

- 12 students from Science and Technology Honors program at UAB were trained at the UAB GATE center in Composites Processing and Testing

- Short workshops for Alabama Nano Bio Science Academy for Teachers Follow-On Meeting at UA with Researchers - Web broadcast / Virtual classroom (UAB, UA, UAH) - 35+ teachers across these institutions, July 2010.

- BioNano Sustainability Consortium - REU/REH (July 29, 2010) - 15 students

- Alabama Boys State Group - Mini-workshop (July 08, 2010) - 18 students

- Southern Company sponsored Middle School Girls student group (ICAN-Girls in Engineering) (Jan 2, 2011)- Mini-workshop 35 students 
- Engineering Academy Students, Hoover, Alabama.- Cuyoha, Valley Christian Academy, Akron, Ohio exchange program(GM mentorship) - Mini-workshop at UAB GATE center (Jan 15, 2011) - 11 students

- Freshman Engineering Training (EGR 200) - Lightweight materials design, processing and validation - 56 students (Spring 2011) - 8 class session, Mini-workshop includes design and build

- GATE faculty is advising Baja Racing Vehicle and Wind Energy related projects in materials by design relationships ( 20 students affected).

- The UAB GATE scholars visited industries (at least 4 industry visits per year). These included companies such as Honda of Alabama (HOA), Mercedes Benz USA, Nucor Steel, US Steel, ACIPCO, VSK, GKN Aerospace in Tallassee and others.. These visits provided the students with a broad range of experience across the automotive manufacturer and the raw material suppliers.

\section{GATE CENTER INTERACTION WITH STATE AUTOMOTIVE COMPANIES}

Several activities were kicked off with Honda of Alabama (HOA), Lincoln, Alabama as part of UAB GATE.

(a) A capstone design team worked on lightweight sheet metal body panel analysis for HOA.

- Melisa Jones (MSE)

- Dustin Noland (MSE)

- Ross Porter (ME)

- Britney Byrd (MSE)

- Brandon Frye (MSE)

- Dante Baldwin (MSE)

These students worked on measuring forming limits of HOAs hood components that were undergoing cracking during manufacture. The students were able to determine the heat treatment correlations to the cause of the cracking and made successful recommendations in producing doors without strain induced cracking at the bends.

(b) In May 2008, GATE fellows and other students visited HOA (Figure 5) to tour the HOA plant and hold discussions on their ongoing GATE research and possibilities of technology insertion into HOA vehicles.

(c) In Summer 2008, Honda of Alabama (HOA) and the UAB GATE students and faculty worked on lightweighting the Honda Odyssey Mini Van for the One Lap of America race that HOA participates in. HOA supplied UAB with sheet metal stampings of the hood and the tailgate of their existing Odyssey Minivan.

The GATE participants went through several design and process iterations in utilizing carbon fiber in conjunction with foam filled honeycomb core and balsa wood core. The final hood was fabricated with 3 layers of satin weave carbon fabric with foam filled honeycomb core and epoxy resin. A mirror finish was obtained on the exposed side of 
the hood, as aesthetics along with weight reduction was a goal. The aluminum hood that HOA currently manufactures weighs $28 \mathrm{lbs}$, while the carbon fiber composite weighed only 6 lbs, a third of the metal part. (Figures 6-8)

The tailgate comprises 3 parts; an inner stiffening frame, and 2 outer panels, one the window receptacle, and the other the bottom panel that houses the tailgate latch and the tail lamps. The parts were optimized for material requirements and each of the three pieces was fabricated with carbon/epoxy using resin infusion processing. The finished parts were trimmed and fit to size along with existing hardware from HOA, such as the tail lamps and the latch. The glass window was replaced with a molded polycarbonate window. The various tooling details for the composite part including that of the window were worked upon in the developmental effort. The metal tailgate assembly of the HOA Odyssey weighs 74 lbs, while the carbon fiber version weighed 44 lbs. (Figures 9-12)

HOA successfully mounted the UAB GATE designed/fabricated parts on the mini-van and used it in their One Lap of America competition. The next steps are developing a range of lightweight parts for the Honda Pilot.

As part of this interaction with HOA, the GATE students have been gaining experience in design and optimization of automotive parts, light weighting concepts, materials selection, processing, properties and testing, modeling and CAD work related to advanced materials use in automotive parts.

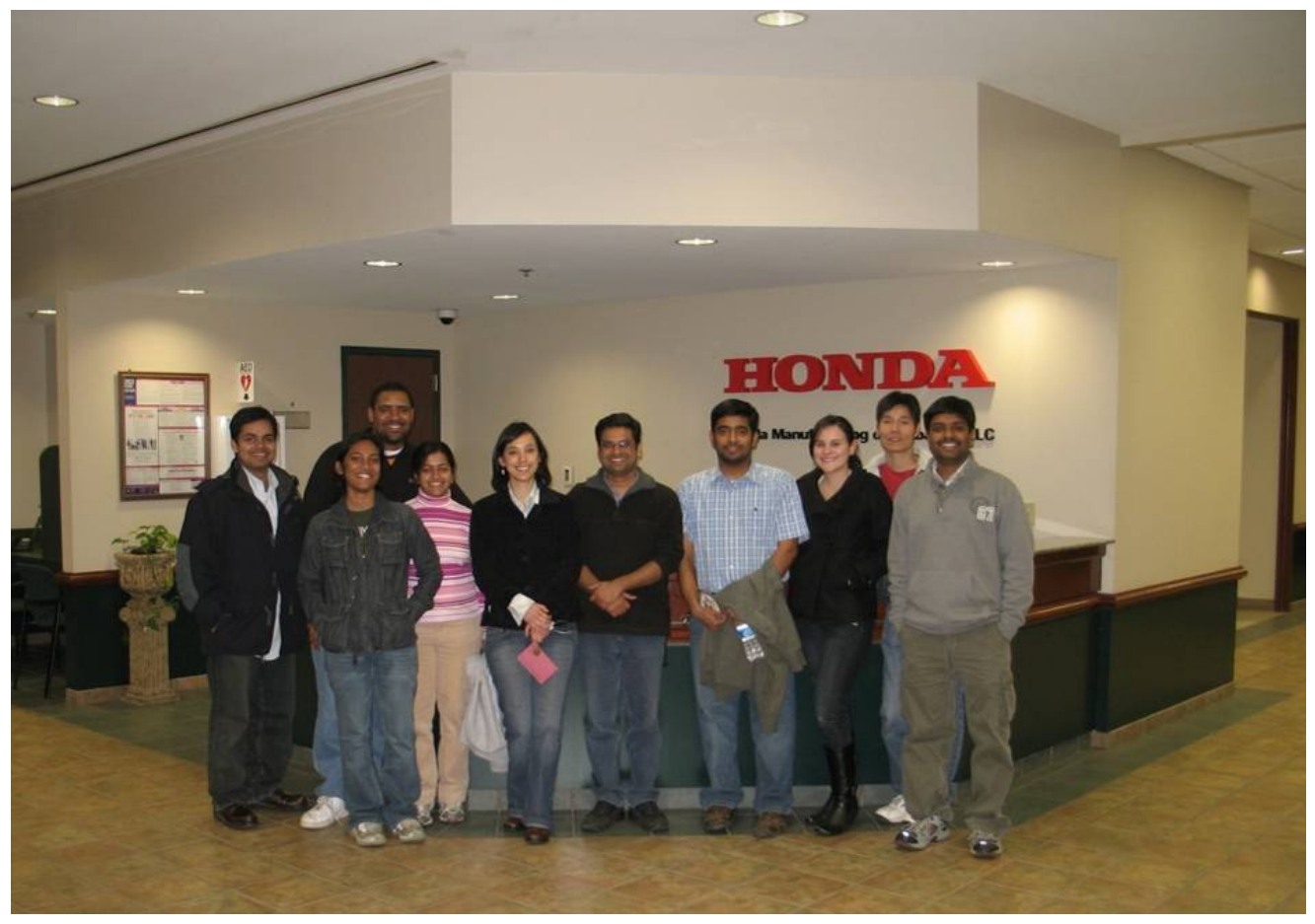

Figure 5. GATE fellows visited HOA for a plant tour and discussion of their GATE research with Honda personnel (Dan Burgess, Bradley Buchanan) 


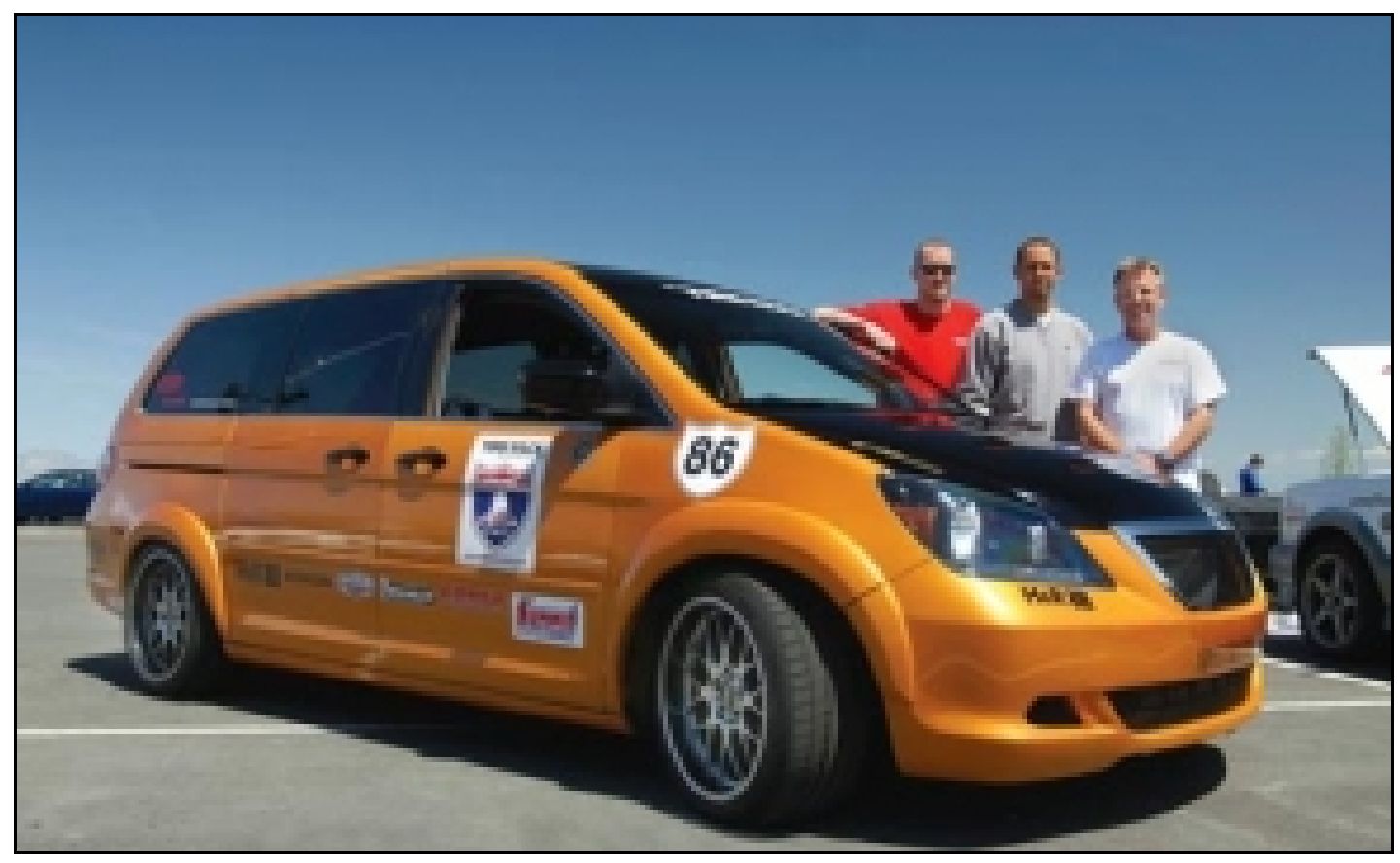

Figure 6. Honda of America’s Odyssey Vehicle that participated in the One Lap of America race

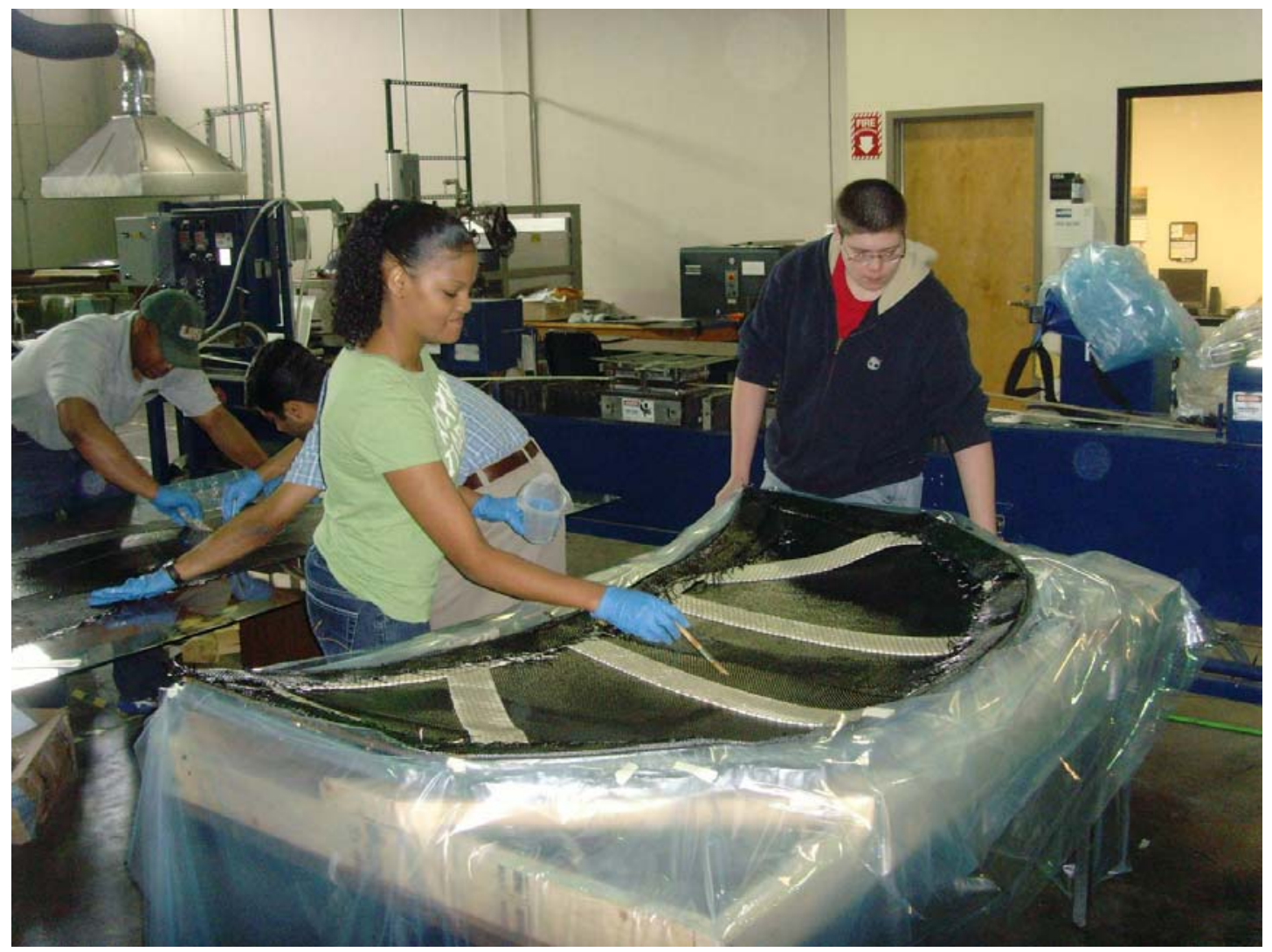

Figure 7. GATE researchers Hadeel Abdelmajeed and Daniel Kaliberov laying up the carbon fiber Odyssey hood at UAB. 


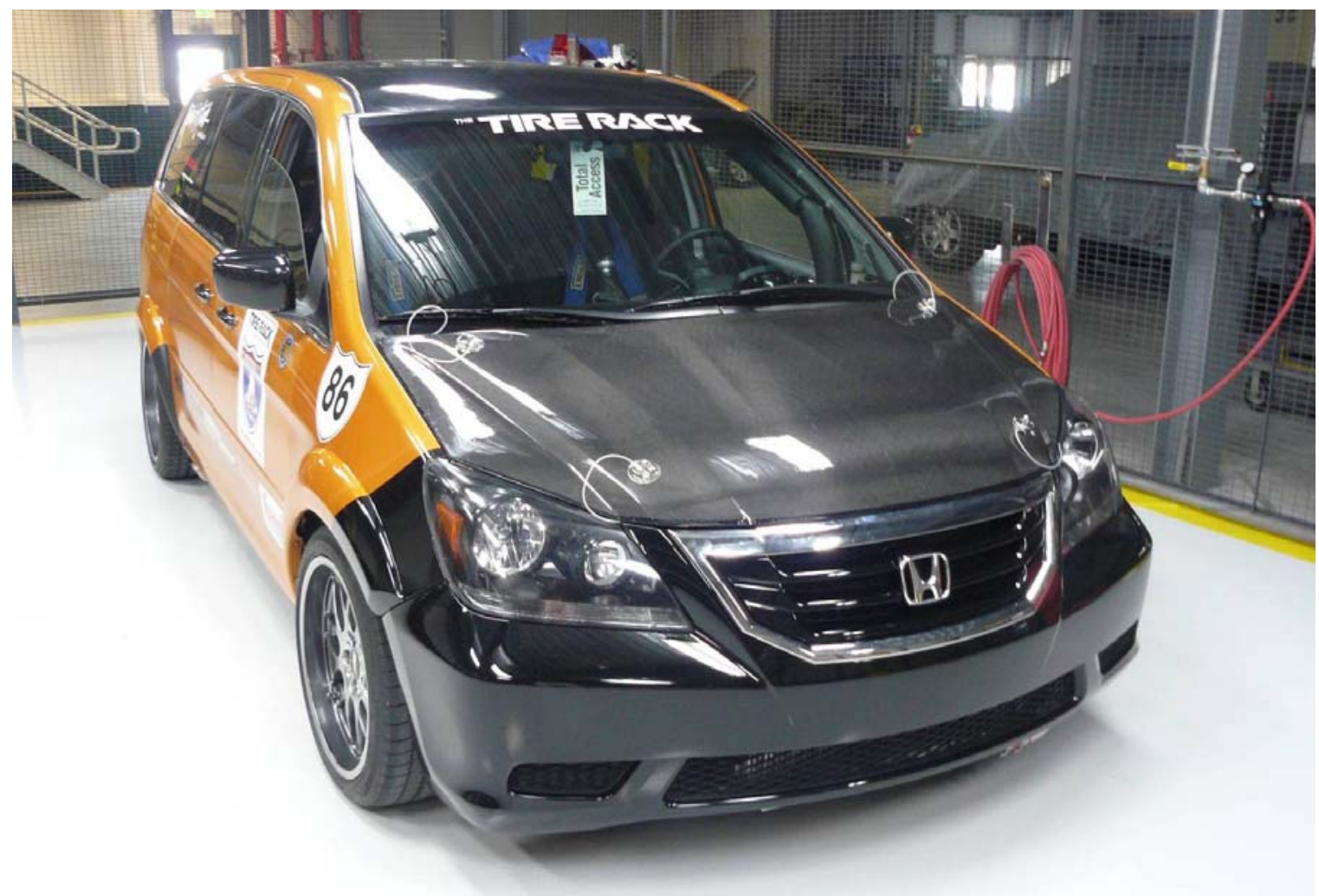

Figure 8. The UAB fabricated carbon fiber hood weighed 8 pounds as opposed to 28 pounds for the steel component it replaced.

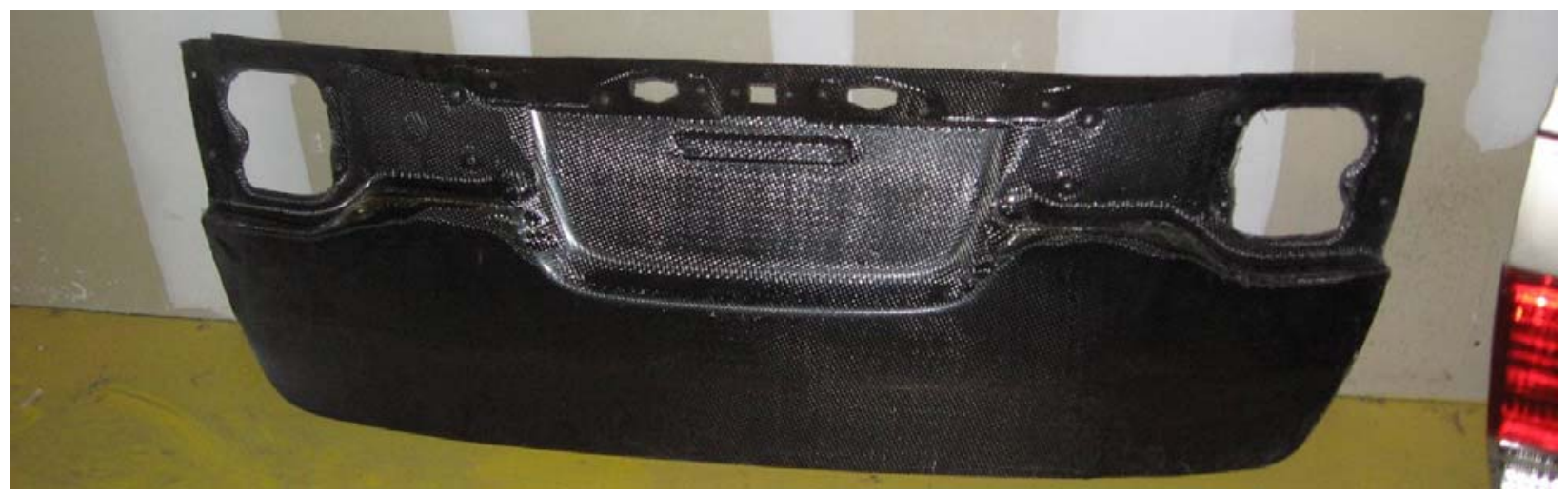

Figure 9. Honda Odyssey tailgate component fabricated using carbon fiber by the GATE fellows. 


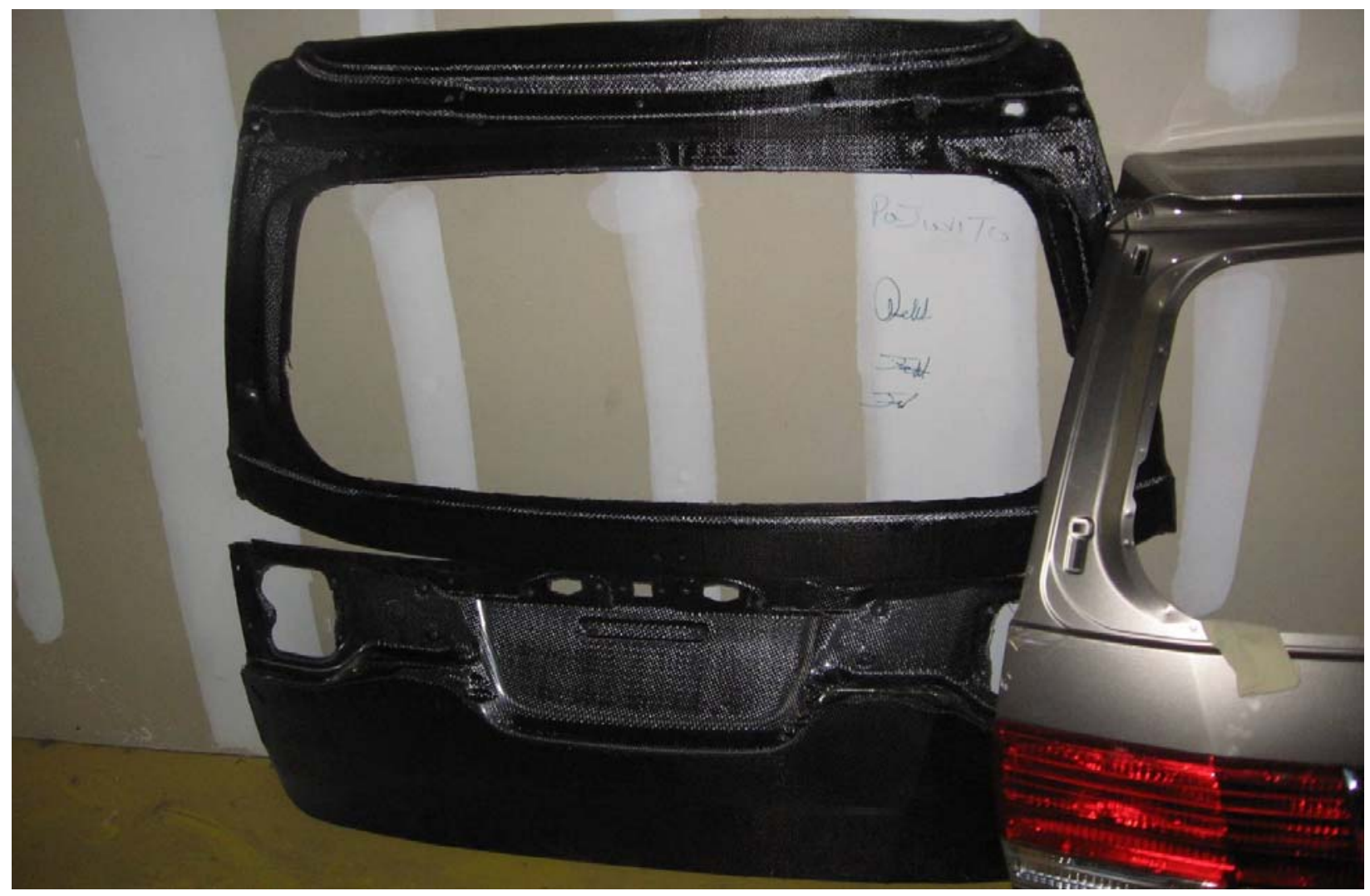

Figure 10. Carbon fiber components of the tailgate fabricated by UAB GATE fellows.

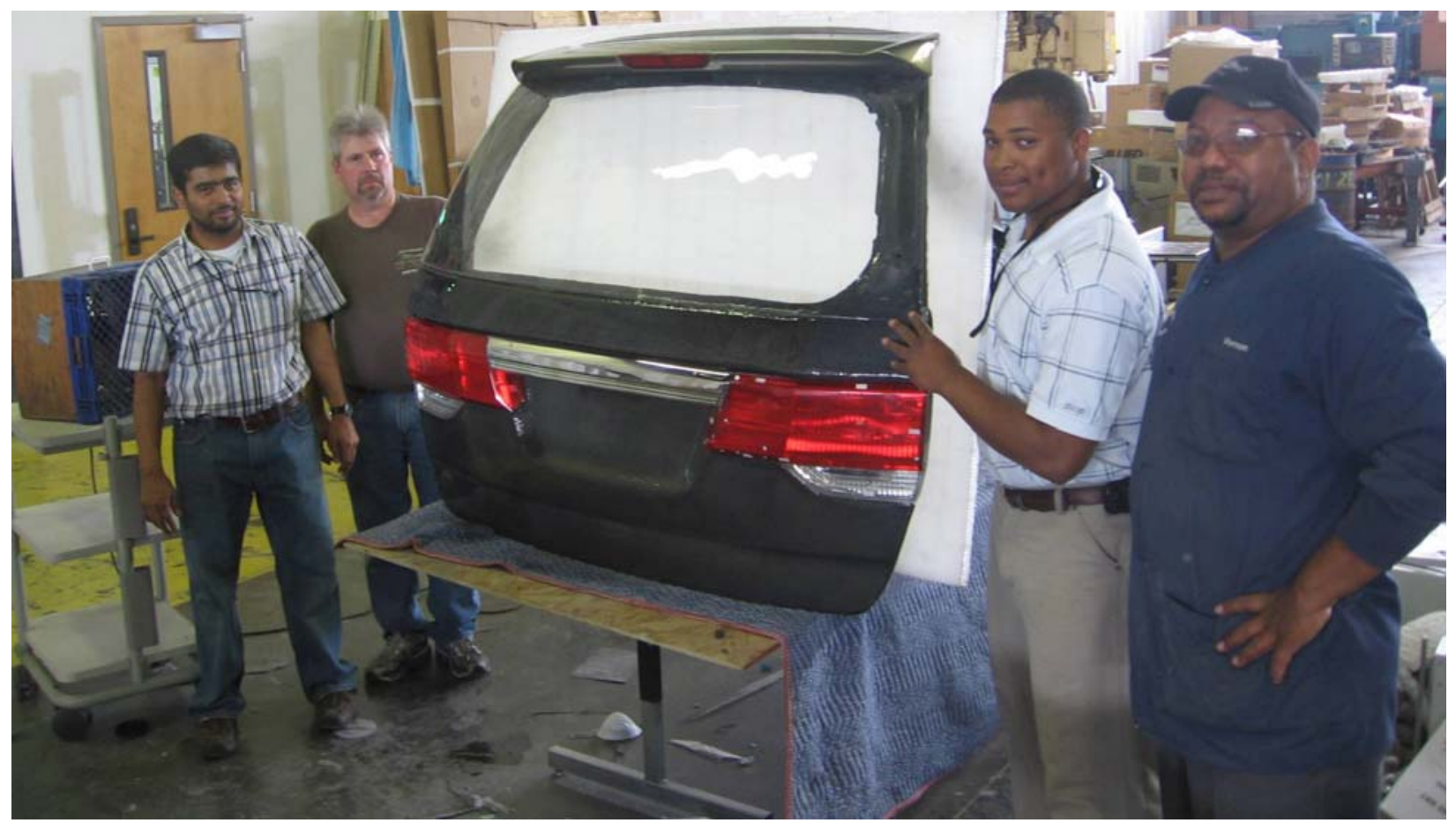

Figure 11. Carbon Fiber Tailgate - 44 lbs with all components (the metal tailgate weighs 74 lbs. GATE researcher Walter Malone and Krishan Thattaiparthasarathy. 

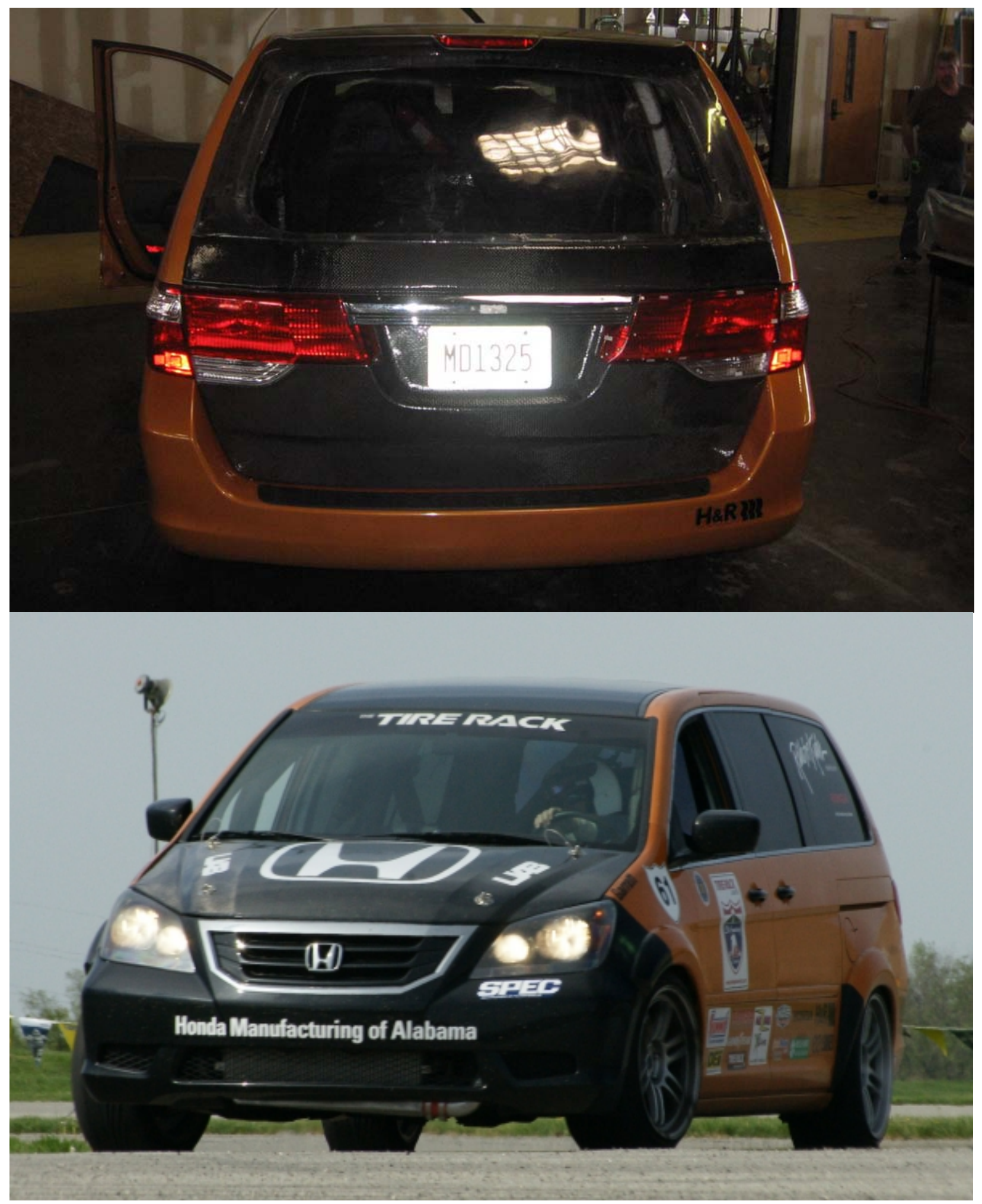

Figure 12. Top: Fully assembled carbon fiber tailgate; and Bottom: The race was held May 2-10, 2008. HOA placed $26^{\text {th }}$ overall out of approximately 80 teams; first in the SUV class. 


\section{J. OTHER RELEVANT INTERACTIONS AND GATE LEVARAGE}

1) Significant interactions took place between the Vance, Alabama Mercedes Benz (MBUSI) and UAB GATE center. Light weighting and advanced materials is of continuing interest to Mercedes.

(a) Team leaders (managers) from the divisions below visited the UAB GATE center as a team on November 02, 2010 and discussed various ways of R\&D interactions as well as recruitment of GATE fellows in the Alabama automotive industries.

(b) Prior to the team visit, Markus Schaeffer, CEO of MBUSI visited the UAB GATE center in August 2010 and emphasized the need for interaction between the Alabama auto industries and academia.

(c) Head of acquisitions of Daimler AG visited the UAB GATE center with BLG Industries (Logistics company for automotive) on Dec 18, 2010 and discussed commercial interests of taking R\&D developments with the GATE focus research to products for Mercedes worldwide. Follow-up discussions on these are being pursued.

2) Significant interactions continued with Toray Carbon Fibers of America (Toray CFA) in hot-melt impregnation of specialized grades of carbon fiber with thermoplastic composites such as PEI, PPS and PEEK. The UAB GATE researchers developed the hot-melt impregnated tapes and conducted the associated thermomechanical characterization studies on these materials.

3) Recycled carbon fiber studies were undertaken in collaboration with Materials Innovation Technologies (MIT) where recycled carbon fibers from aerospace companies are blended with thermoplastic fibers. These discontinuous materials are being considered for insertion of low cost carbon into automotive and transportation applications. The UAB GATE researchers are investigating structure-processing-property relationships for these materials.

4) The collaboration with MIT has led to a follow-up program with Portera Bus where MIT/UAB are collaborating on design and manufacture of bus side skirt made of thermoplastic composites to replace heavy metallic components. The part is in the design phase and prototypes are expected to be delivered to Portera Bus by May 2011. MIT is a recipient of Phase III of a DOE for which UAB is a partner.

5) There have been several visits from automotive collaborators; notably a visit from Daimler Truck, Portland, Oregon. Mark Locetelli and Zach Barra from Daimler visited UAB in December 5, 2010 to discuss collaboration relating to light weighting of trucks.

6) UAB GATE was featured at the UAB booth at the ACMA Composites 2011 show in Fort Lauderdale, February 2011.

7) UAB held a Structural Composites Conference in February 2006, February 2008 (Fig. 8) and August 2010 at the UAB campus. The conference was attended by over 350 attendees and several technical presentations on lightweight composite materials works were made. Rogelio Sullivan, DOE Headquarters and C. Dave Warren have served as session chairs and keynote speakers at this conference.

For example the details of the STRUCTURAL COMPOSITES FOR TRANSPORTATION, DEFENSE, INFRASTRUCTURE AND POWER ENERGY/ August 23-27, 2010, UAB CONFERENCE is briefly explained - 
Continuing on the 2009 theme, the automotive and transportation sectors are shifting to a 'green' outlook as manufacturers are increasingly introducing environmentally friendly structural and functional themes to their design. For example, automotive floor panels, interior trim, horizontal and vertical panels, bumper beams and trunk inserts feature advanced natural fiber composites. However, science and engineering graduates have a limited understanding on integrated design, processing, performance and long-term durability of 'green' plastics and composites.

Natural fibers and bio-based resins are derived from agricultural products. They are environmentally friendly, biodegradable and compared to synthetic glass and carbon fibers, the energy consumption to produce them is very small. The density of natural fibers is in the range of 1.2 to $1.5 \mathrm{~g} / \mathrm{cm}^{3}$, which is lower than glass and carbon fibers. The modulus-to-density ratio of many natural fibers is higher than that of glass fibers. Natural fiber composites can provide comparable impact resistance to glass or carbon fiber composites and increased vibration damping. The price of natural fibers is less than glass and carbon fibers.

There are a range of natural fibers that can be utilized with thermoplastic or thermoset polymer matrices including wheat straw, kenaf, jute, flax, hemp, wood flour, coconut, sisal and banana. The surface treatment, surface adhesion and interface compatibility of natural fibers to polymers such as polypropylene, polyamides and polyurethanes influence the end properties of natural fiber composites, also referred to as biocomposites. Some of the overall limitations of natural fibers are: (a) lower modulus than synthetic fibers; (b) susceptibility to moisture uptake; (c) weak surface adhesion to hydrophobic non polar polymers; (d) lack of availability as broad goods.

Biocomposites are not limited to the use of natural fiber reinforcement. Biobased resins when combined with natural fibers can result in 60-100\% biocomposites. Bio-based resins or bio-blends are obtained by combining unsaturated polyester (UPE) with epoxidized soybean oil (EMS), power plant derived fly ash foam (for energy absorption) and regrind from plastic waste.

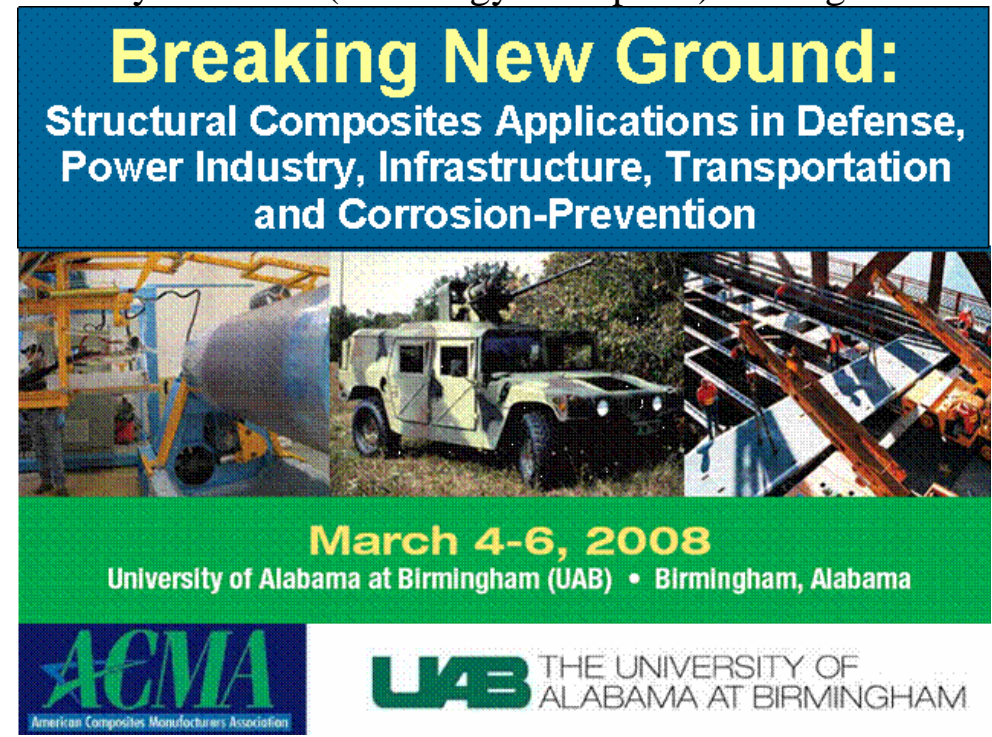

Figure 13. UAB GATE researchers hosted the Structural Composites conference in March 2008. 
The emerging work force of GATE researchers needs to be educated in the utilization of green materials in their thinking in terms of engineering design, processing and integration for technology insertion. GATE faculty members and students were responsible for organizing and spearheading this workshop.

Lawson State Community College, Miles College, Jefferson State Community College, Calhoun Community College and Heritage Center have been involved as community college and community center partners in the UAB GATE. The UAB GATE scholars assisted in the coordination and implementation of the workshop.

Along with instruction at UAB, an interesting aspect of the workshop was the on-line link established with the National Composite Center (NCC) where the students and participants witnessed in real-time the long fiber thermoplastic manufacturing process.

8) The National Science Foundation (NSF) - Advanced Technology Education (ATE) center board is a consortium of 5 Alabama community colleges that offers training and exposure to automotive technologies to their students. The UAB GATE is expected to be an outreach arm for the ATE and we expect number of the 2-year college students getting interested in going on to a 4-year degree.

9) Alabama Germany Partnership : The Alabama Germany Partnership is a resource for information about German companies, events and business opportunities in Alabama and Alabama companies, events and business opportunities in Germany. Various German automotive companies and ancillaries located in Alabama shared their technical needs, internships and employment opportunities in the state. This was an excellent forum for GATE scholars to participate as co-ops, interns and collaborate with these companies offering excellent opportunities. Representative companies included - Mercedes Benz, US VST-Keller, WKW Erbsloeh, and Aluminum Technology Schmid, Hoerbiger and Borgers to name a few.

10) Southeastern Automotive Alliance effort that comprises several southeastern US schools, including UAB, Georia Tech, Mississippi State University, University of Tennessee and Oak Ridge National Laboratory to name a few. The alliance is bringing these partners with complementing strengths to form a team that will address various needs of the automotive industry growth consistent with the developments in the southeastern US.

11) ADVANCED MATERIALS AND FAILURE ANALYSIS WORKSHOP JOINTLY HELD BETWEEN UAB AND Automotive Research Association of India (ARAI) April 19-23, 2010. The need for light weighting of transportation is global. In the May 2009-Dec 2009 period, UAB signed a Memorandum of Understanding (MOU) with the Automotive Research Association of India (ARAI) to promote engineered plastics and composites for light weighting of automobiles, mass transit and truck on an international front. ARAI is the body that certifies all vehicles that run on Indian roads, and they are entirely networked with Industry. Dr. Vaidya held a 5-day workshop at Pune, India (the heart of Indian auto industry). 35 industry participants from companies including Mahindra Navistar, Mahindra Composites, Tata Motors Co, John Deere, Caterpillar, Volkswagen and others were represented. The GATE program and its various successful cases were highlighted and there were significant enthusiasm of the ongoing engineered plastics and composites R\&D with potential insertion into transportation. 


\section{K. INTERACTIONS WITH DOE OAK RIDGE NATIONAL LABORATORY}

- UAB signed on as a partner in the Southeastern Automotive Alliance Consortium comprising Oak Ridge National Laboratory, Battelle, National Transportation Research Center (NTRC) and other universities - Mississippi State University, Georgia Institute of Technology, University of Alabama to name a few.

- Student exchange under ORISE and Oak Ridge University User Agreements resulted in use of high resolution microscopy facilities at Oak Ridge

- Discussions have been held for utilization of high rate testing capability at Oak Ridge for material property evaluation at high strain rates

- Discussions are ongoing to implement Oak Ridge developed process modeling for P4 process of composite materials

- Dave Warren, ORNL served on the UAB GATE advisory board.

\section{INTERACTIONS WITH OTHER INDUSTRY PARTNERS}

The GATE researchers expanded their industry collaborations and a partial listing along with the nature of the collaboration is provided below.

\begin{tabular}{|c|c|c|}
\hline$\#$ & Collaboration & Interaction \\
\hline 1 & Triton PMC, AL & Automotive Parts Manufacturer \\
\hline 2 & Britt Engineering, AL & Fire Suppression - Automotive Floors \\
\hline 3 & North American Bus Industries (NABI), AL & Mass Transit - Components \\
\hline 4 & National Composite Center, OH & Prototyping, Virtual Manufacturing \\
\hline 5 & Shepherd Color Co., OH & Functional Inorganic Paints \\
\hline 6 & Glasforms, AL & Thermoplastic Pultrusion for Transportation \\
\hline 7 & Ticona Inc. & Long Fiber \& Thermoplastic Materials \\
\hline 8 & Propex (CURV) & PP fibers/PP matrix for Body Panels \\
\hline 9 & Toray Carbon Fibers America, Toray CFA & Carbon fiber for automotive \\
\hline
\end{tabular}

\section{GATE SEMINAR SPEAKERS}

A number of speakers have given seminar at the UAB GATE. The list is exhaustive (12-15 speakers per year) and a sampling of these is provided below. 
1) Dr. James Lankford, Southwest Research Institute, Dynamic Strength and Controlling Damage Mechanisms in Metallic Foams, March 25, 2008.

2) Dr. Anil Sachdev., Interdependence of Modeling And Experiments in Design of Automotive Materials., General Motors R\&D Center, April 1, 2008.

3) Dr. Walt Chaput., Foundry Overview, General Motors Defiance Foundary., April 9, 2008.

4) Dr. Alan Druschitz., Magnesium Alloys for Automotive Applications., April 15, 2008.

5) Dr. Mark Poggi., Q-Sense Inc., Quartz Crystal Microbalance with Dissipation: RealTime Analysis of Surface/Chemical Phenomena, April 22, 2008.

6) Dr. John Petrovic, Hydrogen Storage, Los Alamos Laboratory, April 29, 2008.

7) Dr. Paul Swamidass, Tom Walter Business Center, Auburn University, IP and Tech Transfer, May 20, 2008.

8) Lavida Verner, Alabama Technology Network, Green Technology in Alabama Industries, April 2009.

9) Frank Britt., Britt Engineering., Lightweight metals joining for engineered components., February 2009.

10) Dr. Alan Druschitz., Magnesium Alloys for Automotive Applications., June 2009 (GATE MSE 634/734 extended class lecture course).

11) Glenn Kinstler., Economic Development Partnership Agency (EDPA), Alabama Launchpad., May 2009.

12) Dr. Charles Murray, Lawson State Community College, Automotive Electronics, January 2009.

13) Dr. Nitin Chopra, The University of Alabama, "Multi-functionality at Nanometer-Scale: Carbon Nanotubes, Oxide Nanowires, and Nanoparticle-based Heterostructures"

14) Dr. Kyriaki KalaitzidouWoodruff School of Mechanical Engineering, Georgia Tech "Multifunctional Polymer Nanocomposites and Responsive Polymer Particles: The Role of the Interface and Synergy in Nanoscale"

15) Mr. Malcolm BlairVP Technology, Steel Foundry Society of America (SFSA)“Research for the Steel Foundry Industry”

16) Mr. John Griffin Department of Materials Science \& Engineering The University of Alabama at Birmingham "Development of ASTM Digital Reference Radiographic Standards"

17) Mr. Ken Murphy Steel Foundry Superintendent, ACIPCO, “Centrifugal Casting”

18) Dr. Craig Hartley Consultant, Metallic Materials Research and Education A Unified Model for the Mechanical Response of Polycrystals Deforming by both Climb and Glide

19) Dr. Kirill BolotinVanderbilt University, Department of Physics Electrical, mechanical, and chemical properties of graphene

20) Dr. Robin Foley Department of Material Science \& Engineering The University of Alabama at Birmingham Laboratory Safety Training

21) Mr. Santosh B. Ghanti Department of Material Science \& Engineering The University of Alabama at Birmingham The Effects of Solidification Under Pressure on the Porosity and Mechanical Properties of Cast Aluminum Alloys

22) Ahmed Vakili., Univ of Tennessee Space Institute, Pitch Based Carbon Fibers - March 2011

23) Michael Wyzoski., Long Fiber Fatigue Predictive Modeling, American Chemical Council - March 2011 
24) Gnash Deka., Low Cost High Production Rate Carbon Fiber Performs, Neenah Fibers, April 2011.

25) Mark Janney., Recycled Carbon Fiber from Aircraft Waste for Transportation, Materials Innovation Technologies, August 2010

26) USMBI - Mercedez Benz International, Vance, Alabama (Team of Lead Engineers for BIW, Interior, Paint etc. led by CEO Markus Schaeffer) Dec 2010.

27) Daimler Trucks, America - Lead Engineer, Mark Pocatello, Jan 2011.

28) Kirk Atkinson, Bremen Investment and Use Diller, Daimler Procurement, Dec 2010

29) Neman Steel, Hannah Steel, Raymond Monroe American Steel Council members, Aug and Dec 2010.

\section{SUMMARY AND OVERALL ACCOMPLISHMENTS OF UAB GATE Center (2005-2011)}

The major accomplishments and outcome of the DOE GATE during this period can be summarized as below:

- The GATE program for lightweight materials and manufacturing research in composites and metal casting has been a signature program that has drawn the attention state and industry.

- 16 graduate students (8 MS and $8 \mathrm{PhD}$ ) were funded as GATE scholars over the 5-year period. Of these 6 were minority female students (35\% minority students). These students were awarded the GATE certificates for completing the required GATE courses.

- The GATE scholars (including undergraduate GATE scholars) found employment as follows - Automotive, Mechanical and Energy industries (6); Materials producers and suppliers (3); Aerospace (1); National labs (2); Defense (2); Higher studies - PhD (12); Metal casting (3); Finishing BS/Potential GATE scholars (6).

- The program resulted in $22 \%$ increase in graduate student enrollment in UAB Materials R\&D.

- Every $\$ 1$ of DOE GATE investment was leveraged to $\$ 4.5$ in related UAB Materials engineering R\&D.

- DOE relevant technologies were addressed; the knowledge based in long fiber extrusion and injection molding, predictive engineering, high-fidelity computation and modeling, metal casting was expanded.

- Technologies developed were directly applicable to automotive light weighting and energy savings.

- 8 GATE courses were developed and offered at least twice in the 2005-2010 period; which are now part of the curriculum in the School of Engineering.

- The program successfully established pipeline for 21 research experience for undergraduate (REU) students to transition into GATE scholars.

- $300+$ participating institutions students and non-GATE scholars benefited from GATE workshops and outreach activities.

- 72 publications of GATE scholars research appeared in peer-reviewed journals and international conferences.

- A 430-page book was authored by the GATE PI published on Composites for Automotive, Mass Transit \& Heavy Truck (DesTech Publishers) which is a resource for technology user's world-wide. 
- Strong ties were established with Automotive companies - Honda of America (HOA) and Mercedez-Benz US International (MBUSI), ORNL, several ancillaries and material suppliers.

- Economic Development Partnership Agency (EDPA) of Alabama that oversees Alabama industries has integrated UAB GATE as a critical piece of industry-university relationship.

- Three successful Structural Composites for Transportation, Automotive, Energy and Defense conferences hosted were held at UAB in 2006, 2008 and 2010 with DOE GATE, NSF and NACE as co-sponsors. 350+ professionals have attended these for its high technical quality. GATE scholars have presented their research at these conferences.

For additional Information please contact:

Dr. Uday Vaidya

GATE PI

Professor of Materials Science and Engineering

University of Alabama at Birmingham

Birminingham, AL 35294

Phone: 205-934-9199

e-mail: uvaidya@uab.edu 